MARCOS ROGERIO SANCHES BARBETTI

\title{
ESTUDO COMPARATIVO ENTRE COXIM HIDRÁULICO E COXIM ELASTOMÉRICO, APLICADOS AO SISTEMA DE APOIO DO MOTOR AUTOMOTIVO
}

\author{
Trabalho de Conclusão de Curso \\ apresentada a Escola Politécnica da \\ Universidade de São Paulo para \\ obtenção do Título de Mestre junto ao \\ Mestrado Profissional em Engenharia \\ Automotiva.
}




\title{
MARCOS ROGERIO SANCHES BARBETTI
}

\section{ESTUDO COMPARATIVO ENTRE COXIM HIDRÁULICO E COXIM ELASTOMÉRICO, APLICADOS AO SISTEMA DE APOIO DO MOTOR AUTOMOTIVO}

\author{
Trabalho de Conclusão de Curso \\ apresentada a Escola Politécnica da \\ Universidade de São Paulo para \\ obtenção do Título de Mestre junto ao \\ Mestrado Profissional em Engenharia \\ Automotiva. \\ Área de Concentração: \\ Engenharia Automotiva. \\ Orientador: \\ Prof. Roberto Spinola Barbosa.
}


Este exemplar foi revisado e alterado em relação à versão original, sob responsabilidade única do autor e com a anuência de seu orientador.

São Paulo, de setembro de 2005.

Assinatura do autor

Assinatura do orientador

FICHA CATALOGRÁFICA

Barbetti, Marcos Rogério Sanches

Estudo comparativo entre coxim hidráulico e coxim elastomérico aplicados ao sistema de apoio do motor automotivo I M.R.S. Barbetti. -- ed.rev. -- São Paulo, 2005.

$69 \mathrm{p}$.

Trabalho de curso (Mestrado Profissionalizante em Engenharia Automotiva). Escola Politécnica da Universidade de São Paulo.

1.Mecânica automotiva 2.Coxim hidráulico 3.Coxim elastomérico 4.Sistema de apoio ao motor 5.Vibrações de máquinas I.Universidade de São Paulo. Escola Politécnica. Il.t. 
À minha esposa Eliane por toda a sua compreensão pelo tempo disposto a este trabalho. 


\section{AGRADECIMENTOS}

Ao professor Dr. Roberto Spinola Barbosa pelas diretrizes seguras e permanente incentivo.

Aos meus pais que sempre me deram todo o apoio e motivação.

Ao amigo Hans Jurgen Lehinger por toda a atenção e ensinamento.

Ao amigo Amauri Gentil por toda a colaboração e incentivo.

Aos amigos Domingos Cossia Filho e Álvaro Barbugiani por permitirem e facilitarem o processo de pesquisa dentro do nosso ambiente de trabalho. 


\section{RESUMO}

Devido a forte concorrência dentro do mercado automobilístico, aspectos como qualidade e custo tornam-se prioritários na busca de competitividade. Diversas empresas trabalham em propostas visando a redução de custo sem perda de qualidade. Diversos veículos dentro do mercado brasileiro usam o coxim hidráulico no sistema de apoio do motor. A proposta inicial visa substituição deste coxim por um coxim elastomérico. Seguindo esta proposta, tem-se esta pesquisa que visa apresentar comparativamente o comportamento entre o coxim hidráulico e o coxim elastomérico. Além da revisão bibliográfica, realizamos o estudo comparativo experimental com peças físicas avaliadas conforme especificações utilizadas pela indústria automobilística. Observamos que o coxim elastomérico apresentou substancial melhoria desde os anos 70, oferecendo bom compromisso entre rigidez estática e isolação de vibração. O coxim hidráulico, por sua vez, apresenta alto amortecimento na faixa de baixa freqüência e sua rigidez dinâmica ainda é maior na faixa de alta frequiência, porém seu desempenho quanto a isolação de vibração irá depender da rigidez dinâmica, da constante de amortecimento e da faixa de frequiência em estará submetido. Devido ao custo do coxim elastomérico ser cerca de três vezes menor que o custo do coxim hidráulico, o mesmo torna-se grande atrativo para compor o sistema de apoio do motor. Ainda acrescentamos que se deve avaliar o veículo como um todo em laboratórios especializados para avaliação do desempenho quanto ao conforto do usuário. 


\begin{abstract}
Due to strong competition inside of the automotive market, aspects as quality and cost become priority in the search of competitiveness. Several companies work in proposals seeking the cost reduction without quality loss. Several vehicles inside of Brazilian market use the hydraulic mount at their engine mount system. The initial proposal seeks the substitution of this type of mount by an elastomeric mount. Based on this proposal, we have this research that intends to present comparatively the behavior between the hydraulic mount and the elastomeric mount. Besides the researched bibliography, we accomplished the practical comparative study with physical parts evaluating as specifications used by automotive industries. We observed that the elastomeric mount presented substantial improvements since the seventies, offering good compromising between static stiffness and isolation vibration performance. The hydraulic mount presents high damping at low frequency range but its dynamic stiffness at high frequency is larger than elastomeric mount, but its performance at vibration isolation will depend of dynamic stiffness, damping coefficient and of the frequency range that it will be submitted. Due to the cost of the elastomeric mount to be about three times smaller than hydraulic mount cost, the elastomeric mount becomes great attraction to compose the engine mount system. Besides the cost, is evident that should be also evaluate the performance for the user's comfort and new studies in specialized laboratories shall be accomplished.
\end{abstract}




\section{SUMÁRIO}

\section{LISTA DE TABELAS \\ LISTA DE FIGURAS \\ LISTA DE SÍMBOLOS}

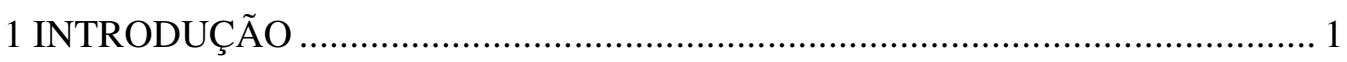

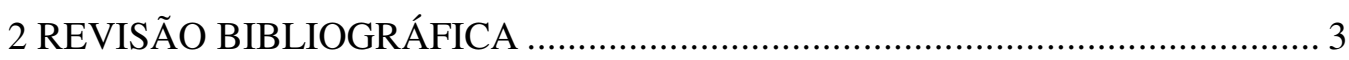

$2.1 \mathrm{O}$ sistema de apoio do motor automotivo ....................................................... 3

2.2 Desempenho requerido para o sistema de apoio do motor. ............................ 4

2.3 Modelamento de um sistema de apoio do motor............................................ 6

2.4 Fundamentos da isolação de vibração ........................................................... 8

2.4.1 Transmissibilidade do sistema de segunda ordem............................... 9

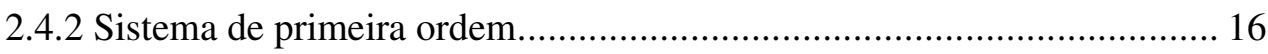

2.5 Rigidez dinâmica e ângulo de fase como propriedades do coxim de motor.... 20

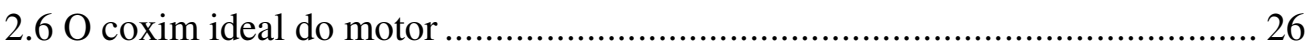

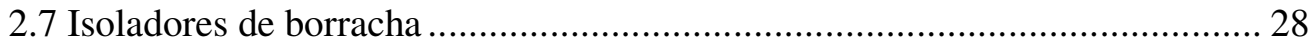

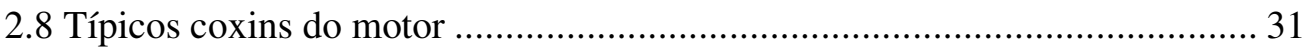

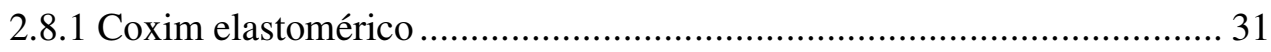

2.8.2 Coxim hidráulico passivo............................................................ 37

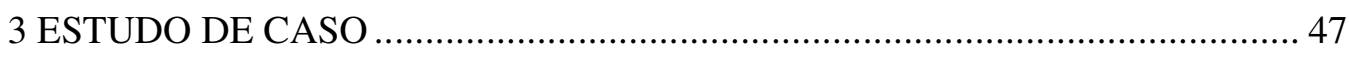

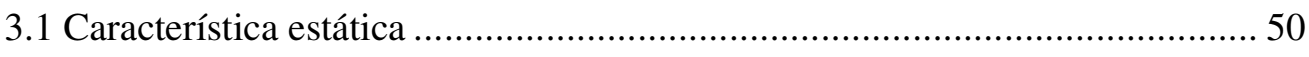

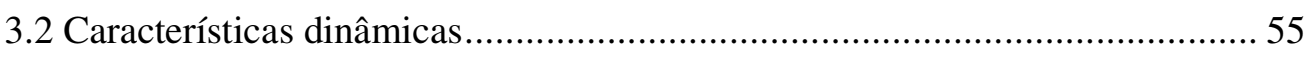

3.2.1 Ensaio em baixa freqüência.......................................................... 58

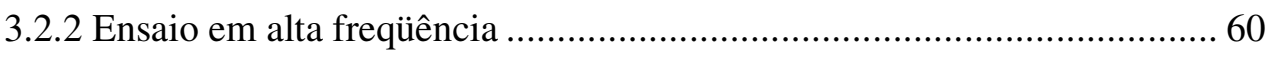

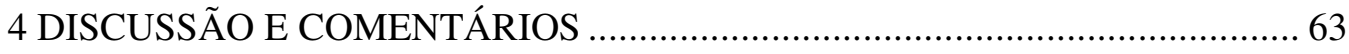

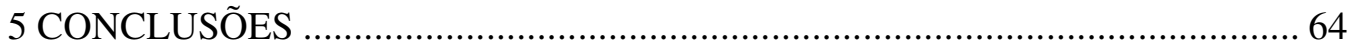

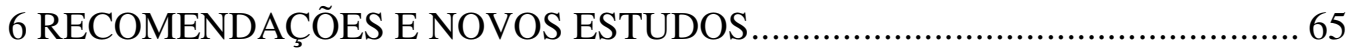

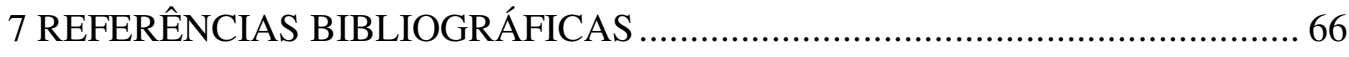




\section{LISTA DE TABELAS}

Tabela 1. Fator de amortecimento para borracha .............................................. 13

Tabela 2. Quadro comparativo entre coxim elastomérico e coxim hidráulico.......... 46 


\section{LISTA DE FIGURAS}

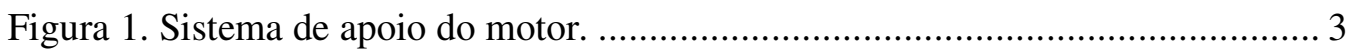

Figura 2. Representação dos seis graus de liberdade do motor. .............................. 5

Figura 3. Modelo de um sistema de apoio do motor.............................................. 6

Figura 4. Conceito de aplicação do isolador de vibração....................................... 9

Figura 5. Isolação de uma máquina desbalanceada em operação............................ 10

Figura 6. Curvas de resposta de um sistema isolador de vibração......................... 12

Figura 7. Transmissibilidade (TR) em função do fator de freqüência $[\beta(=\omega / \omega n)] \ldots 15$

Figura 8. Ângulo de fase entre a resposta de deslocamento e a força de excitação para um sistema com grau de liberdade com amortecimento viscoso excitado por uma força agindo sob uma massa............................................................ 16

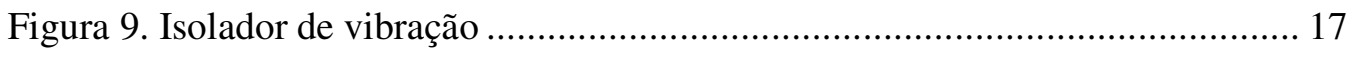

Figura 10. Curva de magnitude logarítmica com as retas tangentes e a curva de

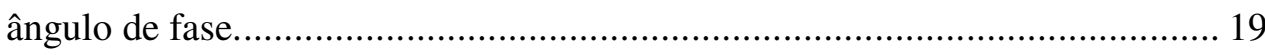

Figura 11. Diagrama carga-deformação em regime dinâmico (Histerese dinâmica). 21

Figura 12. Ilustração da fase entre as funções senoidais de força e deslocamento

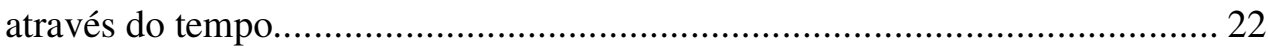

Figura 13. Histerese dinâmica.. ................................................................. 23

Figura 14. Representação dos módulos através de vetores. .................................. 24

Figura 15. Rigidez dinâmica ideal de um coxim de motor ................................. 28

Figura 16. Exemplos de modos de aplicação de carga sob coxins de borracha. ....... 29

Figura 17. Modelo mecânico para o coxim elastomérico ...................................... 31

Figura 18. Rigidez dinâmica e ângulo de fase de um coxim elastomérico ................ 32

Figura 19. Exemplos de coxins elastoméricos da década de 70 .............................. 34

Figura 20. Curva de rigidez estática do coxim elastomérico dos anos 70. .............. 34

Figura 21. Exemplos de coxins elastoméricos da década de 90 ............................ 35

Figura 22. Curva de rigidez estática do coxim elastomérico dos anos 90. .............. 36

Figura 23. Típico coxim hidráulico com orifício longo de inércia e desacoplador... 38

Figura 24. Modelo mecânico para o coxim hidráulico com longo orifício de inércia e

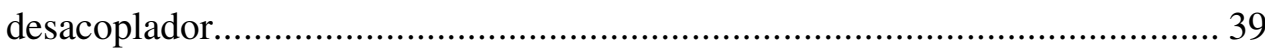


Figura 25. Comparação da rigidez dinâmica e ângulo de fase entre o coxim elastomérico e coxim hidráulico com ranhura de inércia e desacoplador.

Figura 26. Modelo mecânico para o coxim hidráulico com longo orifício de inércia e desacoplador

Figura 27. Rigidez dinâmica e ângulo de fase de um coxim hidráulico com longo

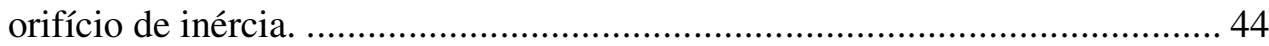

Figura 28. Disposição dos coxins de motor........................................................... 47

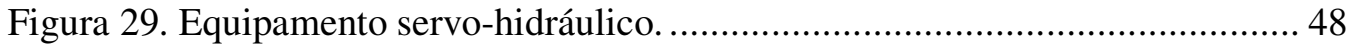

Figura 30. Unidade de carga utilizada na realização dos ensaios........................... 49

Figura 31. Procedimento para determinação do diagrama carga-deformação [F=f(s)].

Figura 32. Indicação da direção da aplicação da força (F) através de eixos. ............ 53

Figura 33. Força (F) aplicada sob os eixos X, Y e Z. .......................................... 54

Figura 34. Aplicação da força F1 junto ao coxim.............................................. 54

Figura 35. Diagrama carga-deformação no sentido -Z ......................................... 55

Figura 36. Representação do diagrama para determinação do ângulo de fase $(\theta)$..... 58

Figura 37. Ângulo de fase em função da freqüência.............................................. 59

Figura 38. Rigidez dinâmica em função da freqüência........................................... 60

Figura 39. Ângulo de fase em função da freqüência.............................................. 61

Figura 40. Rigidez dinâmica em função da freqüência.......................................... 62 


\title{
LISTA DE SÍMBOLOS
}

\author{
C Constante de Amortecimento [Nseg/m] \\ K Constante de Mola [N/m] \\ $\mathrm{x} \quad$ Deslocamento [m] \\ t Tempo [seg] \\ TR Transmissibilidade \\ Ft Força Transmitida [N] \\ Fe Força de Excitação [N] \\ $\beta \quad$ Fator de Freqüência \\ $\omega \quad$ Freqüência da Força de Excitação [rad/seg] \\ Wn Freqüência Natural [ $\mathrm{rad} / \mathrm{seg}]$ \\ M Massa $[\mathrm{kg}]$ \\ m Massa desbalanceada $[\mathrm{kg}]$ \\ r $\quad$ Raio de Giração [m] \\ $\theta \quad$ Ângulo de Fase [rad] \\ $\zeta \quad$ Fator de Amortecimento \\ Cc Coeficiente Crítico de Amortecimento [Nseg/m] \\ G Magnitude \\ X Dado de Saída \\ P Dado de Entrada \\ $\mathrm{T} \quad$ Período $[\mathrm{seg}]$ \\ Fa Amplitude de Força [N] \\ Fm Pré-carga $[\mathrm{N}]$ \\ La Amplitude de Deslocamento [m] \\ $\operatorname{lm}$ Deformação Estática [m] \\ 1 Deformação [m] \\ f Frequiência $[\mathrm{Hz}]$ \\ F Força [N] \\ $\eta \quad$ Fator de Perda \\ Kd Rigidez Dinâmica [N/m] \\ W Energia dissipada em Amortecimento [J]
}




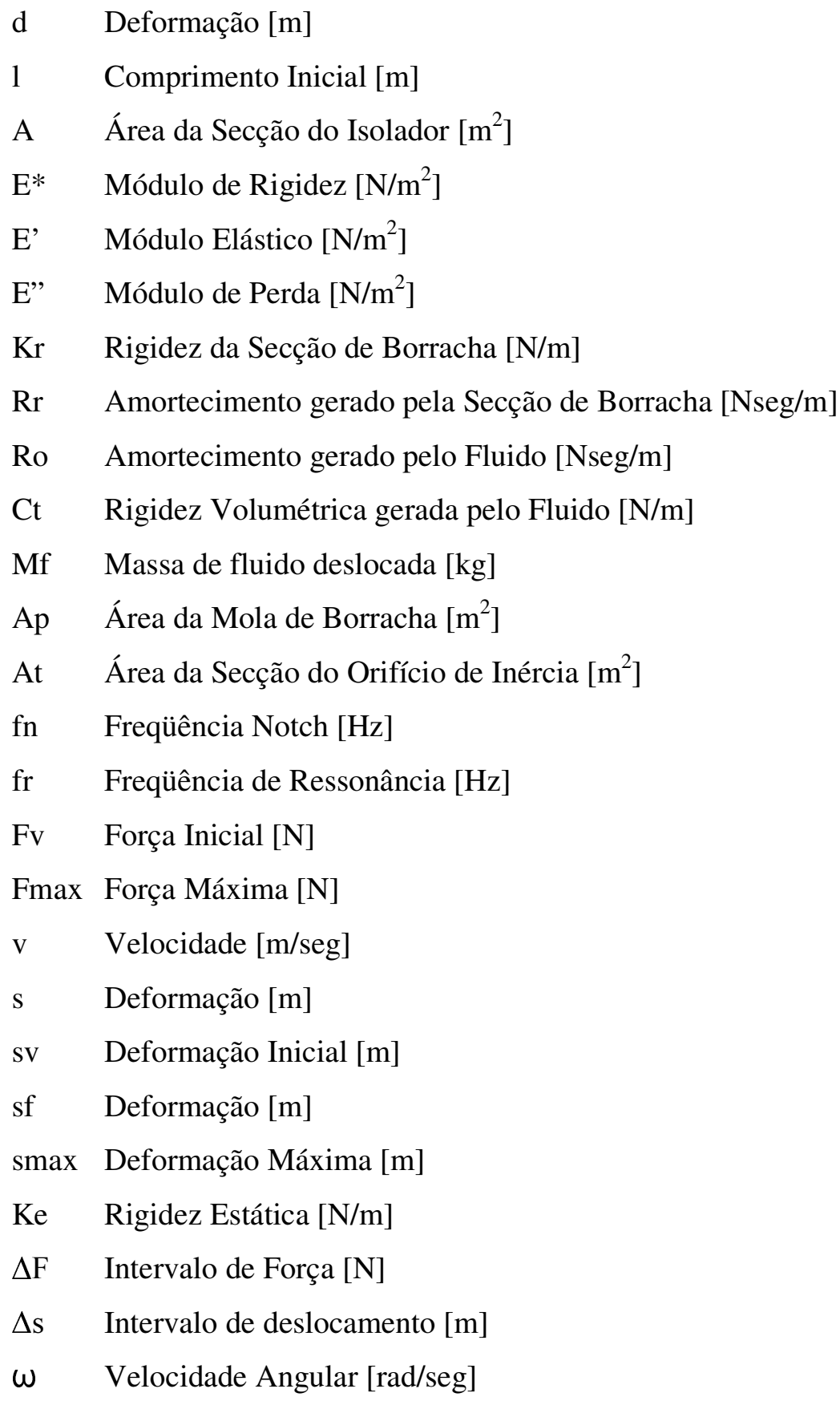




\section{INTRODUÇÃO}

A abertura do mercado brasileiro em meados dos anos 90 permitiu a entrada de empresas estrangeiras no país, diversas montadoras do setor automobilístico tais como as francesas Renault e PSA e as japonesas Honda e Toyota. Estas empresas ao se instalarem no Brasil trouxeram seus produtos bem como sua tecnologia. O mercado automobilístico tornou-se então um cenário de competição ainda mais acirrado para as montadoras que aqui já estavam.

A maioria dos veículos produzidos no Brasil segue o conceito de plataforma mundial, ou seja, o mesmo modelo produzido localmente é similar ao modelo produzido em outros países. A forte competição levou as montadoras aqui instaladas a reverem tal conceito, ou seja, o produto teve que ser adequado às condições do mercado local que tem como característica dois fortes fatores:

1. Melhoria de qualidade: Com a nova diversidade de modelos, a qualidade passou a ser um fator decisivo para a escolha de um veículo;

2. Redução de custo: Devido ao aumento da quantidade de produtos houve um aumento da oferta o que forçou as empresas a colocarem seus produtos a preços competitivos. A busca por redução de custos visando aumento da lucratividade tornou-se atividade prioritária.

A fim de atender a nova condição de mercado, os veículos produzidos localmente passaram a sofrer alterações no projeto original, focado na redução de custo e preservação da percepção da qualidade perante o usuário.

Dentre inúmeras propostas de redução de custo, identificamos que diversos veículos possuem pelo menos um coxim hidráulico dentro do respectivo sistema de coxins de motor. O coxim hidráulico é um componente de alta tecnologia e seu custo pode chegar a três vezes o custo de um coxim elastomérico. Avaliando pelo aspecto de redução de custo, identificamos o potencial da substituição do coxim hidráulico pelo 
coxim elastomérico. Porém tal substituição não deve ser realizada sem as devidas analises, deve-se antes entender a característica de funcionamento de cada tipo de coxim.

Adicionalmente, identificamos através de "bench-marketing" que diversos modelos de plataformas mundiais desenvolveram o coxim elastomérico em substituição ao coxim hidráulico originalmente concebido. Isto mostra a tendência na aplicação do coxim elastomérico em substituição ao coxim hidráulico no setor automotivo.

Dentro deste contexto, este trabalho tem como objetivo avaliar comparativamente as características entre o coxim hidráulico e o coxim elastomérico. Este estudo também poderá ser utilizado como material de referência durante a fase de conceituação de um projeto onde haverá a definição sobre quais tipos de coxins deverão compor o sistema de apoio do motor visando o menor custo e mantendo a qualidade de conforto perante o usuário.

Para este estudo, além da revisão bibliográfica, também iremos apresentar como estudo de caso a comparação experimental entre o coxim hidráulico e o coxim elastomérico, ambos para uma mesma aplicação. 


\section{REVISÃO BIBLIOGRÁFICA}

\subsection{O sistema de apoio do motor automotivo}

O sistema de apoio do motor é composto de diversos coxins que suportam o motor (fonte de vibração) junto à estrutura do veículo (carroceria). O sistema de apoio do motor é ilustrado através da figura 1.

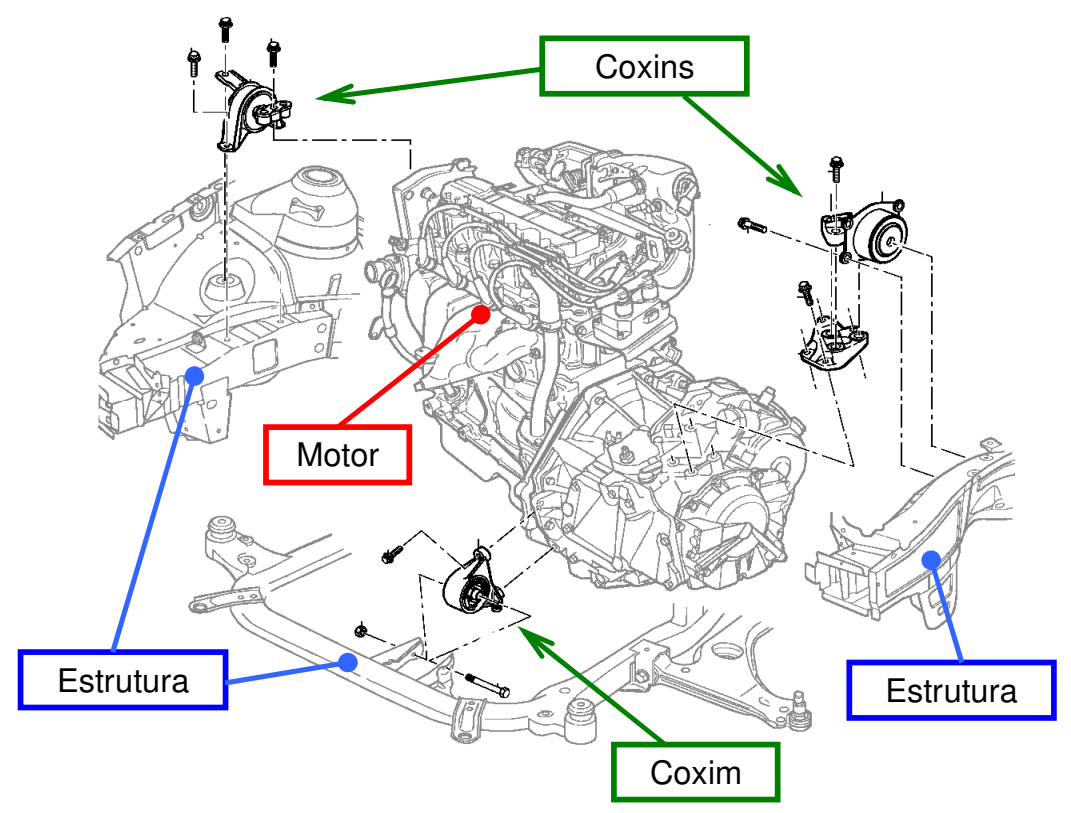

Figura 1. Sistema de apoio do motor.

O objetivo do sistema de apoio é isolar a vibração do motor da carroceria. Com o passar dos anos, o sistema de apoio tem apresentado evoluções na função de isolar o motorista e os passageiros dos ruídos e vibrações gerados pelo motor. Entretanto, segundo Yu, Naganathan e Dukkipati (2001), o sistema de apoio do motor ainda necessita de melhoria devido a dois fatores:

O primeiro fator trata do nível requerido de isolação de ruído e vibração para os passageiros do automóvel. O competitivo mercado automotivo e a necessidade da 
satisfação do cliente levam os requisitos a níveis cada vez mais exigentes, requisitando mais pesquisas nesta área.

O segundo fator é que os projetos atuais tendem para uma carroceria mais leve com motores mais potentes. Os requisitos de redução de peso e o aumento de potência aumentam a excitação vibratória elevando os níveis de vibração e ruído.

Estes dois aspetos estão sempre em conflito e a busca na melhoria do desempenho do sistema de apoio do motor tem como objetivo acomodar ou minimizar tais conflitos.

Diferentes tipos de coxins de motor, do elastomérico (convencional) ao hidráulico e do passivo ao ativo, têm sido desenvolvidos para melhoria do desempenho do sistema.

\subsection{Desempenho requerido para o sistema de apoio do motor.}

De acordo com Rivin (1985), a primeira função do sistema de apoio é suportar o peso do motor. O centro de gravidade do motor não deve estar apoiado em somente um coxim, o apoio deve ser distribuído entre diversos coxins. Isto garantirá que o motor trabalhe livremente mantendo a posição determinada em projeto.

Além de suportar o peso do motor, a função do sistema de apoio é isolar a resultante das forças do motor para a carroceria do veículo. De acordo com Schmitt e Leingang (1976), devido à rotação do motor ocorrem excitações decorrentes dos seguintes fatores:

1. As forças inerciais das massas não balanceadas. Desbalanceamento dos componentes (pistão, biela e virabrequim) em movimento;

2. Transmissão de torque variável. 
Para um motor multi-cilindros, os componentes da força resultante do motor em funcionamento dependem do número e da disposição dos cilindros no motor. Estas forças resultantes excitarão o motor em seis graus de liberdade apresentados em modos de vibração como mostrado na figura 2 (Yu; Naganathan; Dukkipati, 2001). Por exemplo, o torque causado pelo pulso da combustão causará trepidação ao motor. A freqüência da força resultante está relacionada à rotação do motor, número de cilindros e o número de tempos. Para um motor de quatro cilindros, quatro tempos, a freqüência das forças resultantes corresponderá à freqüência de segunda ordem da rotação do motor, devido à ocorrência de dois eventos de combustão para cada volta do virabrequim, segundo Bernuchon (1984), Lee et al. (1994) e Straw (1984), a faixa de freqüência é de 25 a $200 \mathrm{~Hz}$ para a rotação de 600 a $6000 \mathrm{rpm}$ no motor. Para um motor de oito cilindros, a freqüência das resultantes é de quarta ordem da rotação do motor sendo correspondente à faixa de freqüência de 40 a 400 $\mathrm{Hz}$ para a mesma faixa de rotações.

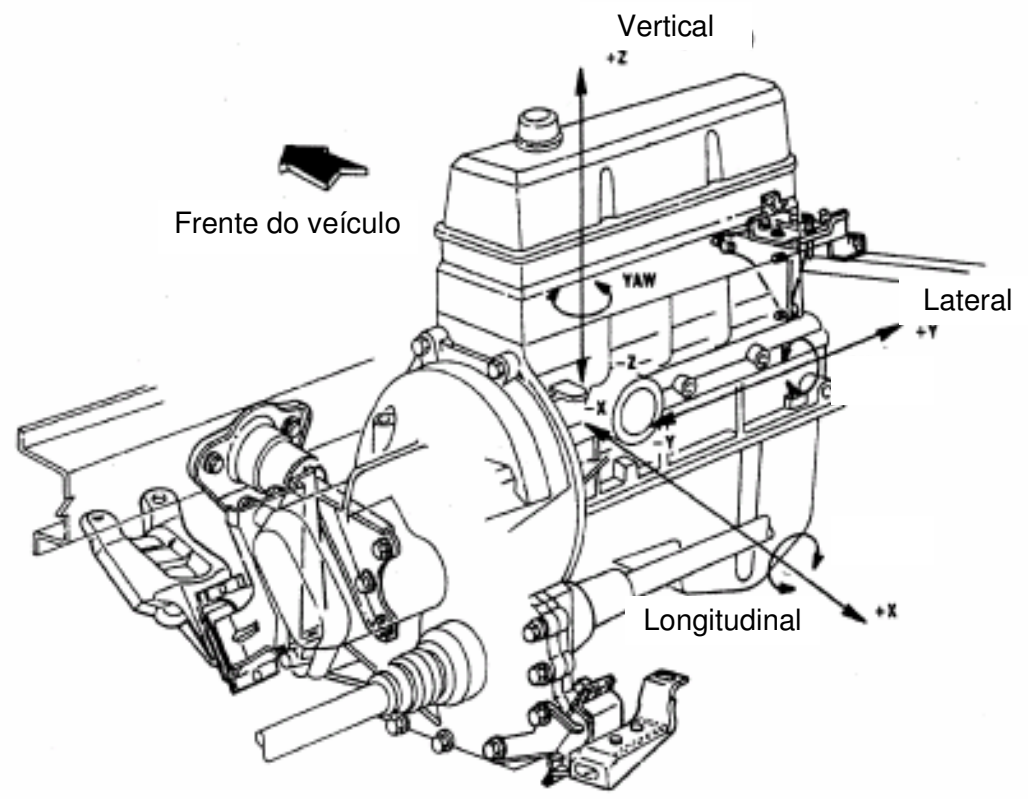

Figura 2. Representação dos seis graus de liberdade do motor (Yu; Naganathan; Dukkipati, 2001).

Em geral, em baixas rotações (marcha lenta), as resultantes do motor promoverão uma trepidação incomoda ao veículo. Em altas rotações, um som intenso é criado 
dentro do veículo quando a freqüência da força resultante coincide com a frequiência de ressonância acústica dos componentes do interior do veículo.

\subsection{Modelamento de um sistema de apoio do motor}

O sistema de apoio do motor consiste geralmente de três ou quatro coxins. O comportamento do sistema não depende somente do desempenho individual dos coxins, mas também do sistema como um todo.

De acordo com Yu, Naganathan e Dukkipati (2001), um típico sistema de apoio do motor é composto por coxins apoiados em uma carroceria (fundação). O motor é livre para oscilar sob estes coxins dependendo da direção das excitações. É razoável considerar o modelo do motor como um corpo rígido, sua freqüência natural é muito maior do que a do sistema motor e coxins. Os coxins são modelados como molas com um coeficiente de rigidez e uma histerese ou viscosidade de amortecimento em cada uma das três principais direções conforme figura 3 (Muller et al., 1996).

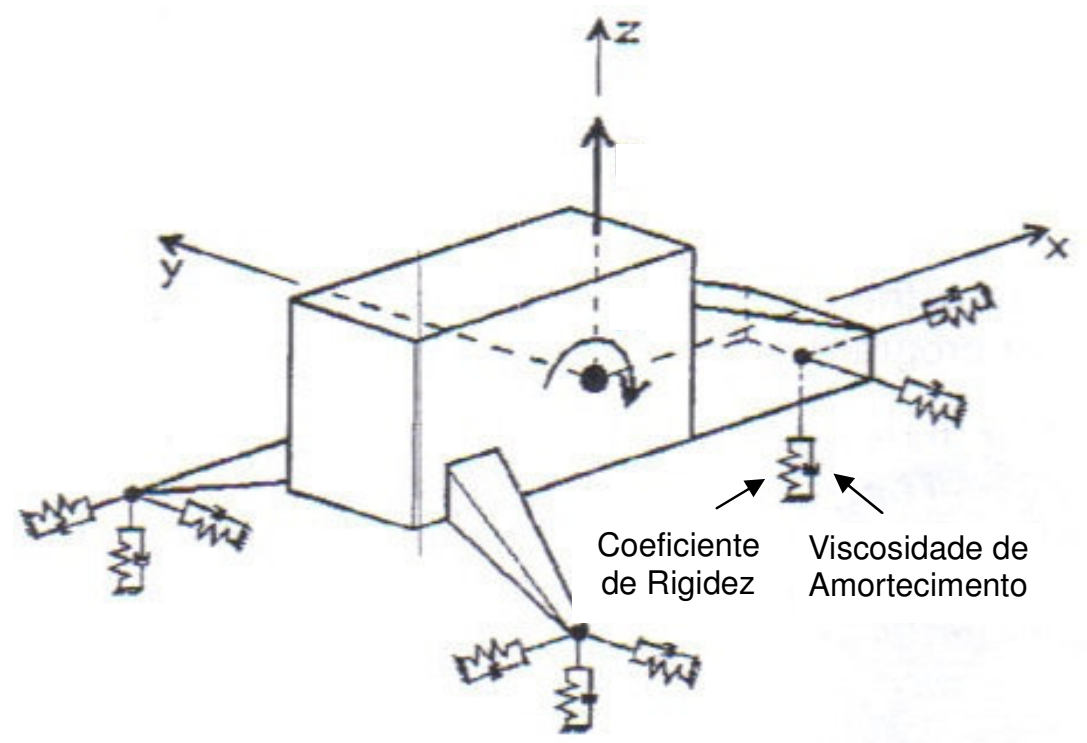

Figura 3. Modelo de um sistema de apoio do motor (Muller et al., 1996). 
Yu, Naganathan e Dukkipati (2001) citam que a fundação também é modelada como um corpo rígido. As razões para excluir as vibrações da fundação são:

1. O deslocamento do coxim fixo na carroceria é pequeno (praticamente nulo) quando comparado ao lado do motor, por isso que o motor e o sistema de apoio são tratados fora do contexto do veículo como um todo;

2. A complexibilidade para desenvolver o sistema de apoio considerando o veículo como um todo;

3. Assim como diversos outros sistemas do veículo, o desenvolvimento do sistema de coxins ocorre usualmente em paralelo à definição completa do veículo.

Considera-se simplificadamente que o motor esteja apoiado sobre coxins na estrutura do veículo parado.

A equação do movimento para os seis graus de liberdade com diversos suportes e uma fundação rígida pode ser escrita conforme eq.(1):

$[M]\{\ddot{X}\}+[C]\{\dot{X}\}+[K]\{X\}=\{F\}$

Onde $X, \dot{X}, \ddot{X}$ são as matrizes de deslocamento de translação e angular, velocidade e aceleração no centro de gravidade do motor, [M] é a matriz da massa rígida do motor, $[\mathrm{K}]$ é a matriz do complexo sistema de rigidez, e [C] é a matriz da viscosidade de amortecimento. $\{\mathrm{F}\}$ representa a matriz das forças e momentos de excitação. Usando esta equação, a resposta dinâmica e o objetivo da função do sistema podem ser facilmente derivados. Parâmetros de projeto tais como locação, orientação, coeficientes de rigidez e amortecimento estão todos incluídos no sistema de equações.

Entretanto, no sistema de um veículo real, existem os vários modos de vibração da carroceria devido ao sistema de suspensão que são chamados de excitações externas. 


\subsection{Fundamentos da isolação de vibração}

O conceito mecânico da aplicação de um coxim de motor é baseado na isolação de vibração de um sistema de vibração forçada com amortecimento viscoso.

Segundo Harris e Crede (1976), a isolação de vibração é o processo na qual os efeitos vibratórios são reduzidos ou até mesmo eliminados. A função do isolador de vibração é reduzir a magnitude das forças transmitidas da máquina para sua fundação ou para reduzir a magnitude do movimento transmitido da vibração da fundação para a máquina.

Neste estudo, estamos considerando o motor como fonte de vibração (máquina) que transmite vibração para a carroceria (fundação) através da oscilação da força resultante dos pulsos de combustão e do desbalanceamento dos componentes do motor. Assumindo o papel de isolador de tal vibração, temos o coxim de motor (suporte) na qual é o objeto deste estudo.

O conceito é mostrado na figura 4 (Ogata, 1998). Aqui o sistema consiste de um corpo rígido representando uma máquina conectada a uma fundação através de um isolador que consiste de uma mola e um amortecedor. A figura 4 ilustra o caso onde a fonte de vibração é dada pela oscilação da força originada pela máquina (excitação devido ao desbalanceamento). O isolador reduz a força transmitida para a fundação. 

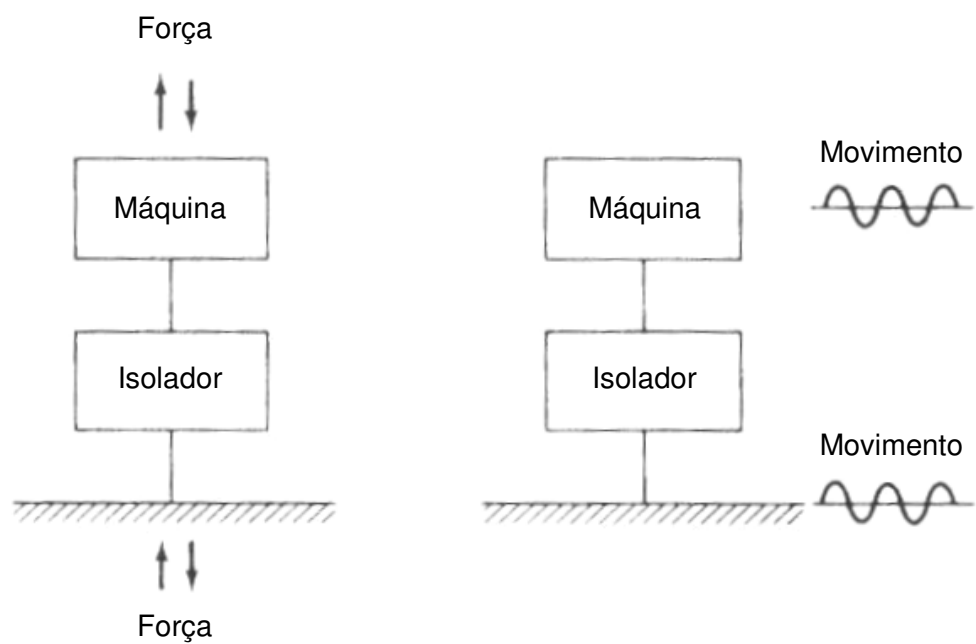

Figura 4. Conceito de aplicação do isolador de vibração (Ogata, 1998).

\subsubsection{Transmissibilidade do sistema de segunda ordem}

Conforme Ogata (1998), transmissibilidade é a taxa da redução da força transmitida por um isolador. Se a fonte de vibração é a oscilação da força devido ao desbalanceamento da máquina (força de excitação), transmissibilidade é a razão da amplitude da força transmitida para a fundação sobre a amplitude da força de excitação.

Para o sistema massa, mola e amortecedor mostrado na figura 5 (Ogata, 1998), a fonte de vibração é a força resultante gerada pelo desbalanceamento da máquina em operação. 


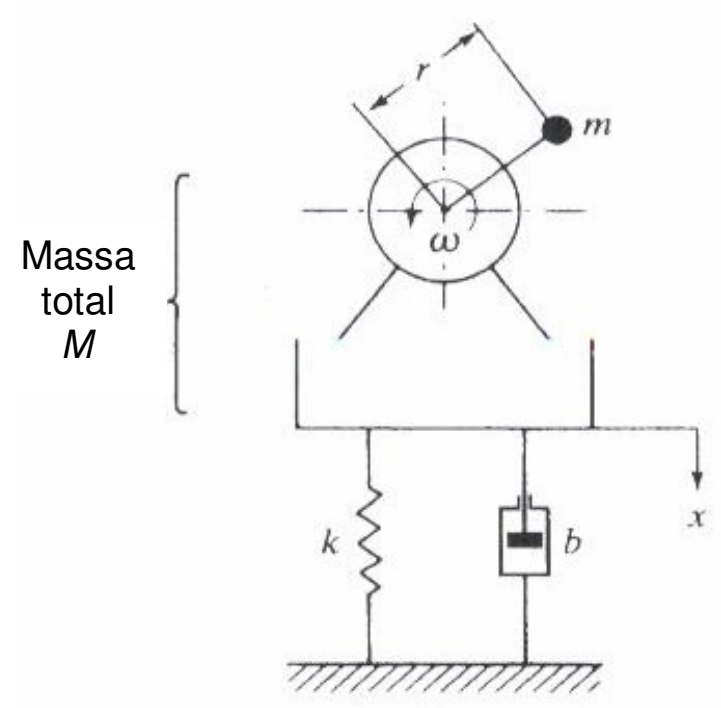

Figura 5. Isolação de uma máquina desbalanceada em operação (Ogata, 1998).

A transmissibilidade neste caso é a razão da amplitude das forças conforme eq.(2):

Transmissibilidade $=T R=\frac{F t}{F e}=\frac{\text { Amplitude_da_Força_Transmitida }}{\text { Amplitude_da_Força_de_Excitação }}$

Vamos colocar a transmissibilidade em termos do fator de amortecimento $(\zeta)$ e do fator de freqüência $(\beta)$, porém antes vamos conhecer conceitualmente estes fatores.

O fator de freqüência $(\beta)$ é a razão entre a freqüência da força de excitação e a frequiência natural do sistema massa, mola e amortecedor e é dada conforme eq.(3).

$\beta=\frac{\omega}{\omega n}$

Onde:

$\beta=$ Fator de frequiência.

$\omega=$ Freqüência da força de excitação.

$\omega n=$ Frequiência natural da massa em suspensão. 
A freqüência natural ( $\omega n)$ ou freqüência natural não-amortecida é a freqüência livre de vibração de um sistema não amortecido, a freqüência natural é dada conforme eq.(4):

$\omega n=2 . \pi \cdot f=\sqrt{\frac{K}{M}}$

Onde:

$\omega n=$ Freqüência natural da massa em suspensão.

$\mathrm{K}=$ Rigidez (Constante de mola).

M = Massa em suspensão.

$\mathrm{f}=$ Freqüência de excitação

O fator de amortecimento ( $(\zeta)$ para um sistema com amortecimento viscoso é a razão entre o coeficiente de amortecimento (C) e o coeficiente de amortecimento crítico (Cc) e é representado conforme eq.(5).

$$
\varsigma=\frac{\text { Coeficiente_de_amortecimento }}{\text { Coeficiente_crítico_de_amortecimento }}=\frac{C}{C c}=\frac{C}{2 \sqrt{K \cdot M}}=\frac{C}{2 \cdot M \cdot \omega n}
$$

Onde:

$\mathrm{C}=$ Coeficiente de amortecimento

$\mathrm{Cc}=$ Coeficiente crítico de amortecimento.

$\mathrm{K}=$ Rigidez

M = Massa em suspensão

$\omega n=$ Freqüência natural 
Temos que Harris e Crede (1976) e Ogata (1998) apresentaram a definição de amortecimento e amortecimento crítico:

- Amortecimento é a dissipação de energia através do tempo ou deslocamento;

- Amortecimento crítico é o mínimo amortecimento viscoso que irá permitir um sistema em movimento retornar à sua posição inicial sem oscilação.

Analisando a condição de razão de amortecimento, podemos destacar os três casos abaixo e ilustrados na figura 6 (Ogata, 1998).

Caso 1. Sub-amortecido $(0<\zeta<1)$. O sistema oscila em torno da posição inicial. Caso 2. Amortecimento crítico $(\zeta=1)$. Raramente o sistema terá esta condição, neste momento o sistema deixa de gerar oscilações durante o amortecimento.

Caso 3. Super-amortecido $(\zeta>1)$. O movimento é amortecido para a posição inicial sem oscilar.

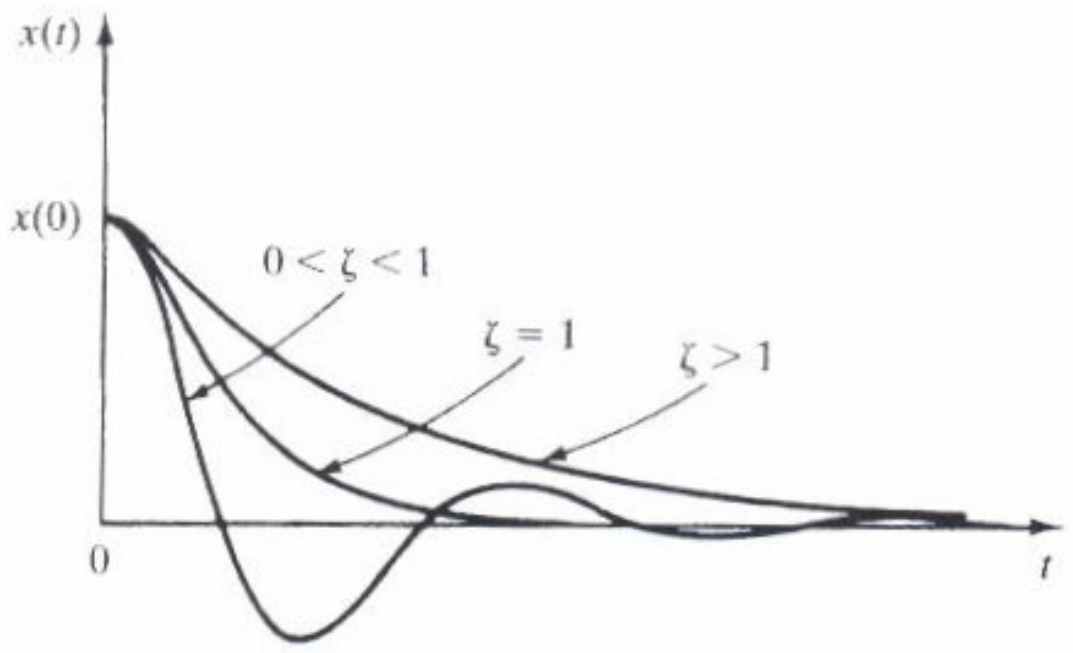

Figura 6. Curvas de resposta de um sistema isolador de vibração (Ogata, 1998).

Neste trabalho estaremos destacando o coxim de borracha como isolador de vibração, segue na tabela 1 (Harris; Crede, 1976) os valores representativos do fator 
de amortecimento (C / Cc) aplicados a alguns tipos borracha. É necessária uma faixa de tolerância para cada polímero devido à variação de dureza e formulação.

\begin{tabular}{|c|c|}
\hline Polímero & Fator de Amortecimento $(\mathbf{C} / \mathbf{C c})$ \\
\hline Estireno Butadieno & $0,05-0,15$ \\
\hline Metil Butadieno & $0,01-0,08$ \\
\hline Policloroprene & $0,03-0,08$ \\
\hline Butílica & $0,05-0,50$ \\
\hline
\end{tabular}

Tabela 1. Fator de amortecimento para borracha (Harris; Crede, 1976).

A força de excitação em um dado instante de tempo é causada pela massa desbalanceada da máquina e é obtida conforme eq.(6):

$$
p(t)=m \cdot \omega^{2} \cdot r \cdot \sin (\omega \cdot t)=F e \cdot \sin (\omega \cdot t)
$$

Onde:

$\mathrm{m}=$ Massa desbalanceada .

$\mathrm{r}=$ Raio de giração.

$\mathrm{Fe}=$ Amplitude da força de excitação.

$\omega=$ Velocidade angular .

$\mathrm{t}=$ Tempo

A equação do movimento do sistema é dada conforme eq.(7) abaixo:

$M . \ddot{X}+C . \dot{X}+K . X=p(t)$

Onde:

M = Massa em suspensão.

$\mathrm{C}=$ Coeficiente de amortecimento.

$\mathrm{K}=$ Rigidez.

$\mathrm{X}=$ Deslocamento. 
A força transmitida para a fundação é a somatória do amortecimento e da força da mola, desta forma temos a eq.(8):

$$
f(t)=C \cdot \dot{x}+K . x=F t \cdot \operatorname{sen}(\omega . t+\theta)
$$

Onde:

$\mathrm{Ft}=$ Amplitude da força transmitida.

$\omega=$ Velocidade angular

$\mathrm{t}=$ Instante de tempo.

$\theta=$ Ângulo de fase.

M = Massa em suspensão.

$\mathrm{C}=$ Coeficiente de amortecimento.

Aplicando a transformada de Laplace e as devidas substituições, temos a eq.(9):

Transmissibilidade $=T R=\frac{F t}{F e}=\frac{\sqrt{1+(2 . \zeta . \beta)^{2}}}{\sqrt{\left(1-\beta^{2}\right)^{2}+(2 . \zeta . \beta)^{2}}}$

Na eq.(9), identificamos que a transmissibilidade depende do fator de freqüência ( $\beta$ ) e do fator de amortecimento (ろ). É importante destacar que quando $\beta=\sqrt{2}$, a transmissibilidade é igual a 1e independente do valor do fator de amortecimento (ろ). 


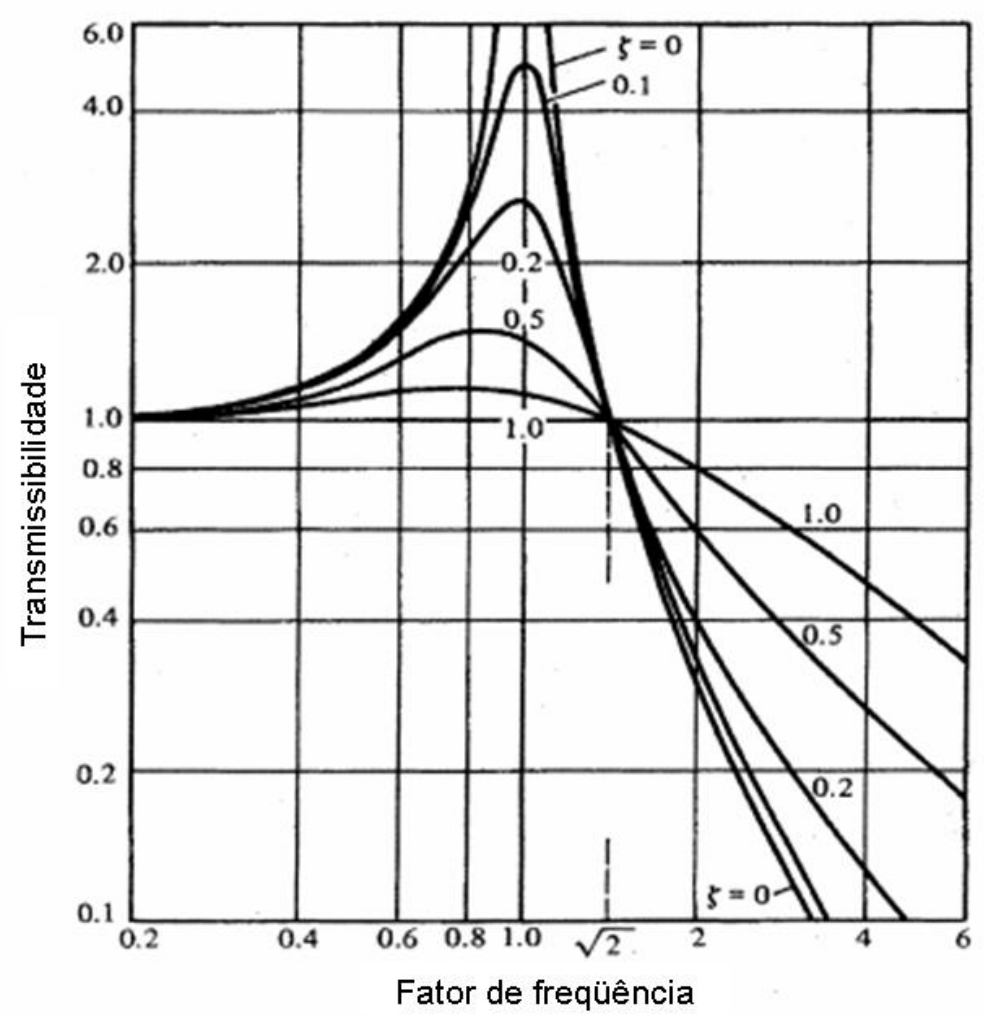

Figura 7. Transmissibilidade (TR) em função do fator de freqüência $[\beta(=\omega / \omega n)]$ (Yu; Naganathan; Dukkipati, 2001).

A figura 7 (Yu; Naganathan; Dukkipati, 2001), mostra a transmissibilidade em função do fator de freqüência ( $\beta$ ). Conforme apresentado por Hartog (1972), Harris e Crede (1976) e INMAN (1996), podemos observar que todas as curvas passam pelo ponto crítico, onde $\mathrm{TR}=1$ e $\beta=\sqrt{2}$. Para $\beta<\sqrt{2}$, conforme o fator de amortecimento $(\zeta)$ aumenta, a transmissibilidade diminui. Para $\beta>\sqrt{2}$, conforme o fator de amortecimento $(\zeta)$ aumenta, a transmissibilidade também aumenta.

Além da transmissibilidade, observa-se o efeito sobre o ângulo de fase em função do fator de freqüência e do fator de amortecimento conforme figura 8 (Harris; Crede, 1976). A freqüência da força de excitação é a mesma freqüência do deslocamento (deformação) do sistema, porém tais freqüências não oscilam no mesmo tempo, existe uma defasagem ou atraso entre elas. $\mathrm{O}$ ângulo de fase especifica a quantidade 
na qual a freqüência de deslocamento atrasa em função da freqüência da força de excitação.

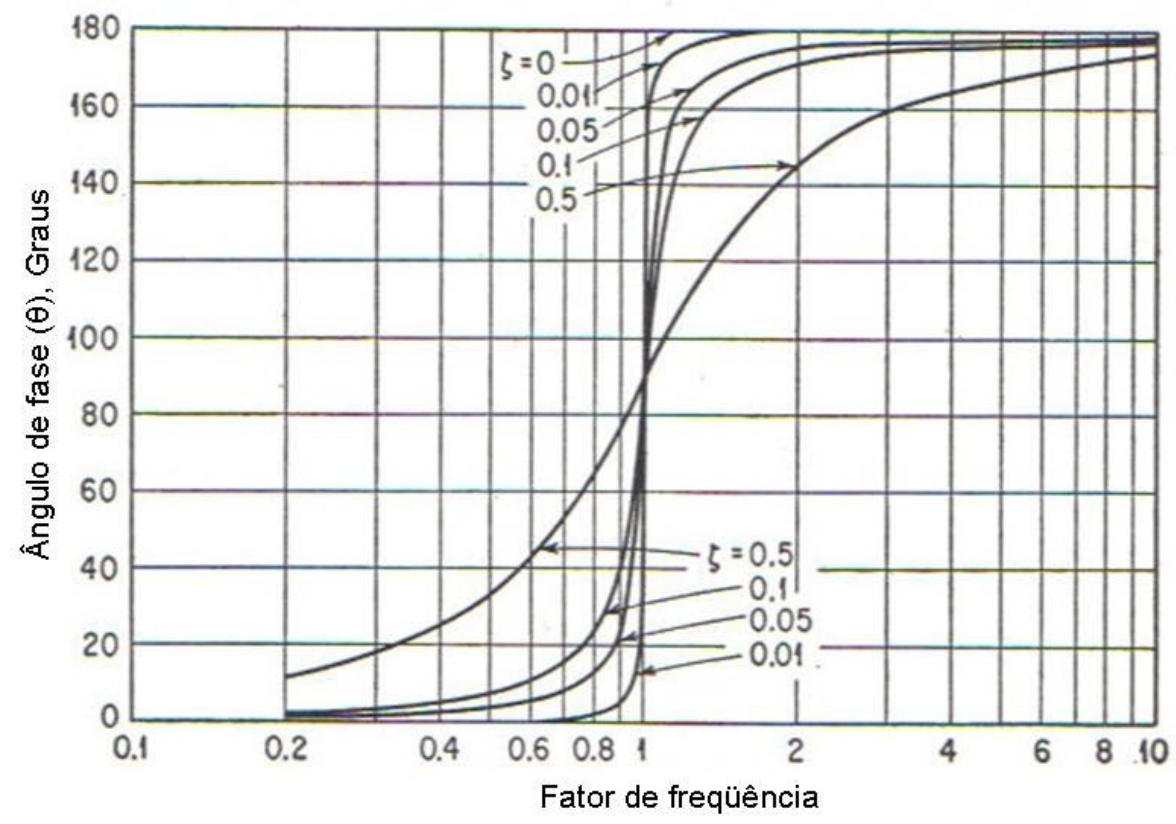

Figura 8. Ângulo de fase entre a resposta de deslocamento e a força de excitação para um sistema com grau de liberdade com amortecimento viscoso excitado por uma força agindo sob uma massa (Harris; Crede, 1976).

\subsubsection{Sistema de primeira ordem}

Um isolador consiste essencialmente de um meio elástico (mola) para suportar a carga e um meio para dissipar energia (amortecedor). Um típico isolador de vibração é mostrado na figura 9 (Ogata, 1998). Um simples isolador de vibração pode ser um componente de borracha capaz de realizar ambas as funções de suportar carga e dissipar energia. 


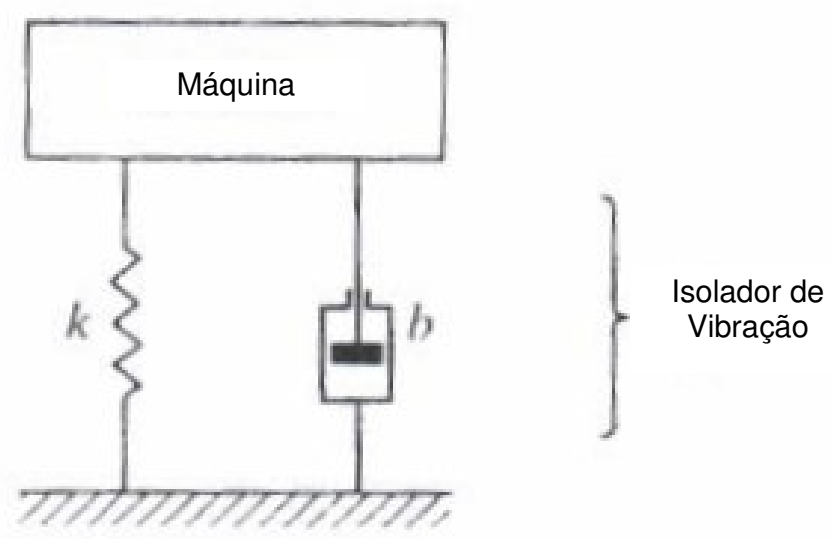

Figura 9. Isolador de vibração (Ogata, 1998).

O isolador de vibração é modelado como uma mola associada em paralelo com um amortecedor e é representado conforme eq.(10):

$C \cdot \dot{X}+K . X=p(t)$

Onde:

$\mathrm{C}=$ Constante de amortecimento.

$\mathrm{K}=$ Constante de mola.

$\mathrm{X}=$ Deslocamento.

$\mathrm{t}=$ Tempo.

Segundo Ogata (1998), o diagrama de amplitude e fase, conhecido como diagrama Bode, é uma forma muito útil para representar as características de um sistema dinâmico. Para nossa aplicação, iremos apresentar o diagrama Bode como uma função de transferência senoidal e resultados experimentais da resposta da freqüência. Com este recurso, iremos considerar o coxim isoladamente usando o sistema de primeira ordem.

A função de transferência senoidal pode ser representada por dois gráficos separados, um fornecendo a magnitude versus a freqüência e outro fornecendo o ângulo de fase 
(em graus) versus freqüência, desta maneira o diagrama Bode consiste de dois gráficos: um é o gráfico logaritmo da magnitude da função da transferência senoidal; o outro é o gráfico do ângulo de fase; ambos representados com frequiência em escala logarítmica.

A representação logarítmica padrão da magnitude $[\mathrm{G}(\mathrm{j} \omega)]$ é $20 \log [\mathrm{G}(\mathrm{j} \omega)]$. A unidade utilizada para representar a magnitude é o decibel $(\mathrm{dB})$. Segundo Harris e Crede (1976), o decibel é a unidade na qual indica a razão entre a quantidade de entrada e a quantidade de saída de dada magnitude, em termos de logaritmo.

Consideremos a função de transferência senoidal conforme eq.(11):

$$
\frac{X(j \omega)}{P(j \omega)}=G(j \omega)=\frac{1}{T j \omega+1}
$$

Onde:

$\mathrm{X}=$ Dado de saída

$\mathrm{P}=$ Dado de entrada

$\mathrm{G}=$ Magnitude

$\mathrm{T}=$ Período

$\omega=$ Velocidade angular

j = Número complexo

O logaritmo da magnitude da função transferência senoidal de um sistema de primeira ordem em decibéis é dado conforme eq.(12).

$$
20 \log \left|\frac{1}{T j \omega+1}\right|=-20 \log \sqrt{\omega^{2} T^{2}+1}
$$

Conforme a figura 10 (Ogata, 1998), a representação logarítmica da curva de resposta da freqüência da magnitude $G(j \omega)$ pode ser aproximada por duas retas tangentes, uma reta tangente a $0 \mathrm{~dB}$ para a faixa de freqüência $0<\omega<1 / \mathrm{T}$ e outra linha 
tangente com inclinação $-20 \mathrm{~dB} /$ dezena para a faixa de freqüência $1 / \mathrm{T}<\omega<\infty$. Desta maneira, temos a figura 10 que apresenta a curva de magnitude logarítmica com as retas tangentes e ângulo de fase. A magnitude representa a relação entre o dado de entrada e o dado de saída enquanto o ângulo de fase representa o atraso do dado de saída em relação ao dado de entrada.

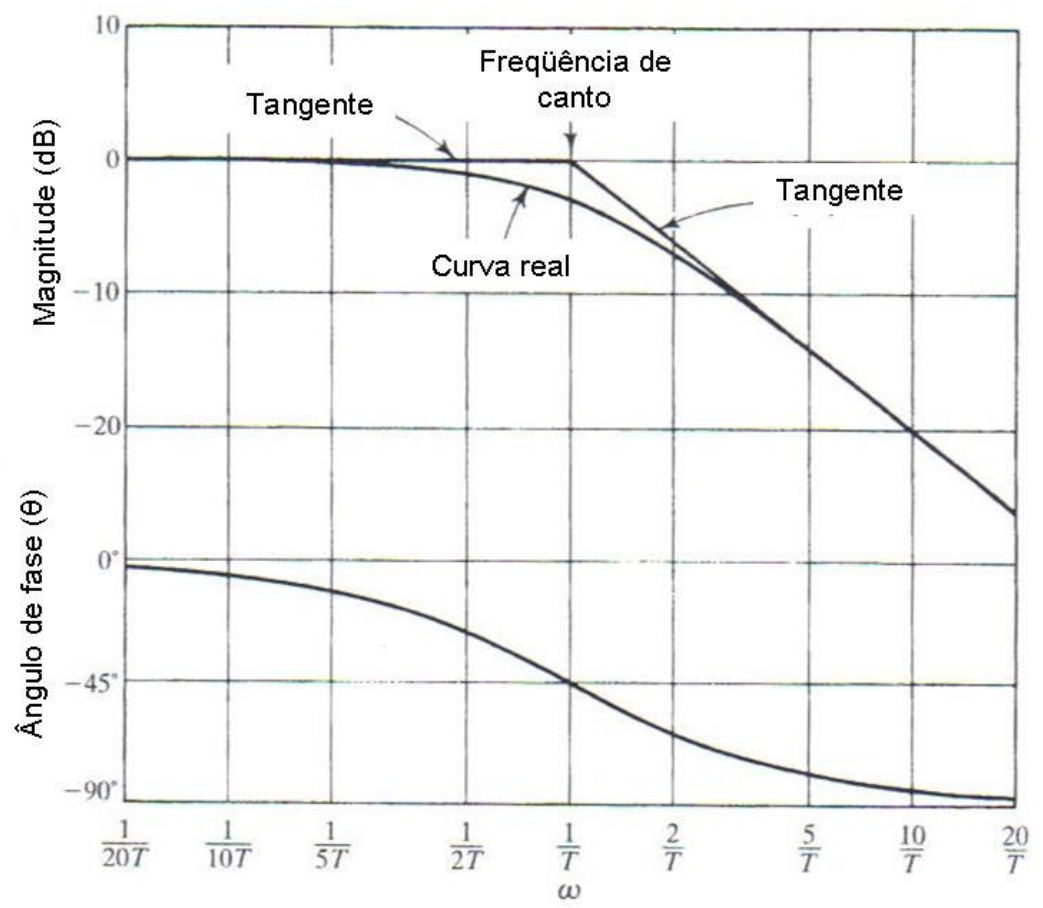

Figura 10. Curva de magnitude logarítmica com as retas tangentes e a curva de ângulo de fase (Ogata, 1998).

A freqüência na qual as duas retas tangentes se encontram é chamada de frequiência de canto ou freqüência de mudança de inclinação (quebra). Para o fator $1 /(T j \omega+1)$, a freqüência $\omega=1 / \mathrm{T}$ é a freqüência de canto desde que em $\omega=1 / \mathrm{T}$ as retas tangentes tenham o mesmo valor. A freqüência de canto divide a curva de freqüência de resposta em duas regiões: região de baixa freqüência e região de alta freqüência. 
O exato ângulo de fase $(\theta)$ do fator $1 /(\mathrm{Tj} \omega+1)$ é dado conforme eq.(13):

$\theta=-\tan ^{-1}(\omega T)$

Na freqüência de canto, o ângulo de fase é dado conforme eq.(14):

$\theta=-\tan ^{-1}\left(\frac{T}{T}\right)=-\tan ^{-1}(1)=-45^{\circ}$

Para o infinito, o ângulo de fase tende a $-90^{\circ}$. Como o ângulo de fase é dado por uma função inversa da tangente, o ângulo de fase é inclinado simetricamente sobre o ponto de inflexão onde temos $\theta=-45^{\circ}$.

\subsection{Rigidez dinâmica e ângulo de fase como propriedades do coxim de motor.}

Conforme a norma DIN 53513 (1990), dentro de um regime estático, imagina-se o coxim isento da carga do motor. Para esta situação, temos a carga e o deslocamento nulos, quando o motor é apoiado ao coxim, temos a pré-carga (Fm) e o deformação estática $(\mathrm{Lm})$.

Quando em regime dinâmico, a resultante das forças do motor atua sobre o coxim impondo uma amplitude de força $(\mathrm{Fa})$ com uma freqüência (f). A aplicação da amplitude de força $(\mathrm{Fa})$ gera conseqüentemente uma amplitude de deslocamento (La), tal regime leva à formação de uma histerese dinâmica tomando a forma de uma elipse devido à característica de amortecimento do coxim de borracha conforme citado por Flower (1995). A histerese dinâmica é apresentada na figura 11 (DIN 53513, 1990). 


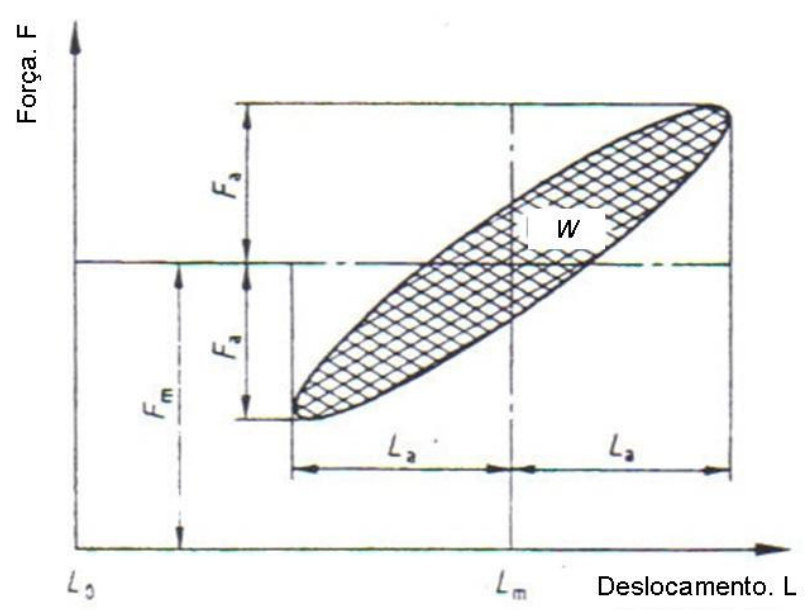

Figura 11. Diagrama carga-deformação em regime dinâmico (Histerese dinâmica) (DIN 53513, 1990).

Quando realizamos testes baseados na variação por força, uma distinção deve ser feita entre pré-carga (Fm) na qual é uma força constante e sua amplitude de força (Fa) que varia ao longo do tempo. Para a variação senoidal excitada em uma freqüência (f), a força (F) em um dado instante de tempo (t) é dada conforme eq.(15):

$$
F=F m+F a \cdot \sin (\omega . t)
$$

Onde:

Fm = Pré-carga.

$\mathrm{Fa}=$ Amplitude de força

$\omega=$ Velocidade angular $(\omega=2 . \pi . f)$

$\mathrm{t}=$ Tempo.

A deformação (L) do material em dado instante de tempo considerando o material com comportamento linear, na qual é independente da magnitude da amplitude de força $(\mathrm{Fa})$ é dado conforme eq.(16):

$L=L m+L a \cdot \sin (\omega t-\theta)$ 
Onde:

Lm = Deformação estática

$\mathrm{La}=$ Amplitude do deslocamento

$\theta=$ Ângulo de fase

$\omega=$ Velocidade angular $(\omega=2 . \pi . f)$

$\mathrm{t}=$ Tempo.

A variação no tempo da amplitude de deslocamento (La) tem a mesma frequiência (f) que a amplitude da força $(\mathrm{Fa})$, porém com um atraso especificado pelo ângulo de fase $(\theta)$, conforme representado na figura 12 (DIN 53513, 1990).

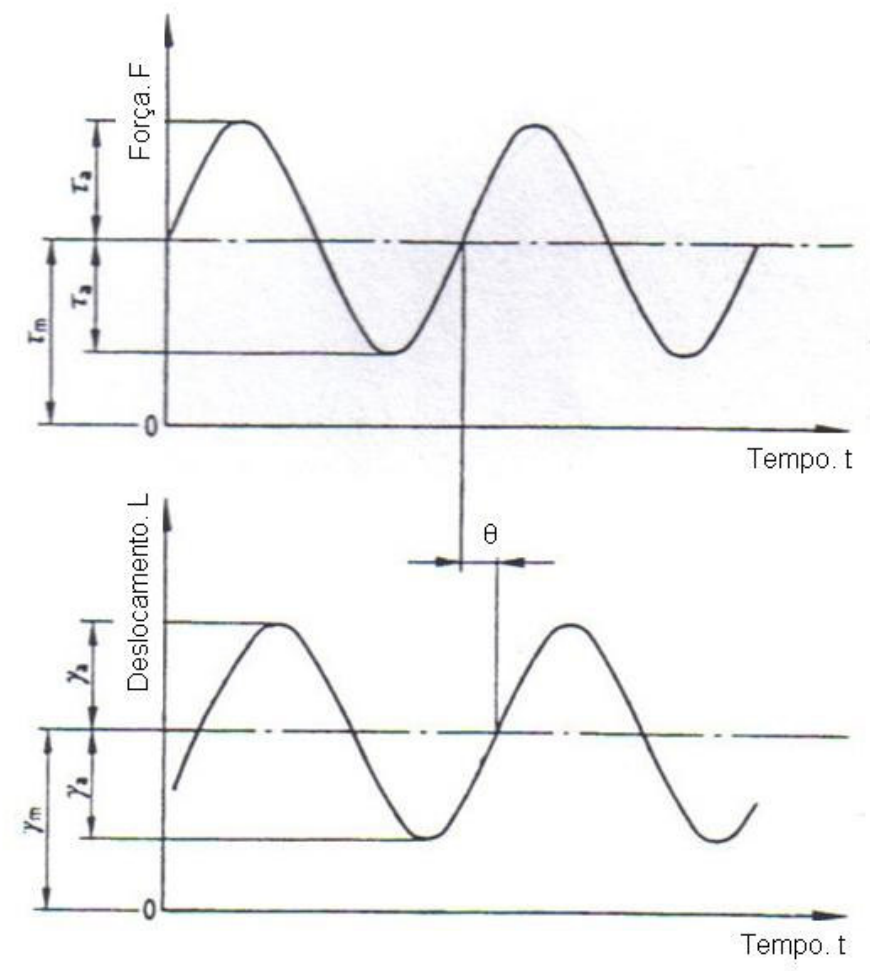

Figura 12. Ilustração da fase entre as funções senoidais de força e deslocamento através do tempo (DIN 53513, 1990).

Para caracterizar o comportamento visco-elástico do coxim sob condições dinâmicas de deformação, duas características devem ser especificadas: o fator de perda e a rigidez dinâmica. 
O fator de perda ( $\eta)$ é definido pela eq.(17):

$\eta=\tan (\theta)$

Onde o ângulo de fase $(\theta)$ especifica a quantidade pelo qual a freqüência do deslocamento (deformação) esta defasada em relação a freqüência de aplicação de força conforme apresentado na figura 12.

Dentro deste contexto, temos a rigidez dinâmica $(\mathrm{Kd})$ em função da freqüência (f) que é determinada através da razão entre a amplitude da força ( $\mathrm{Fa}$ e da amplitude do deslocamento (La) originada pela histerese dinâmica apresentada na figura 13 (MTS, 1993) e pela eq.(18) abaixo:

$K d=\frac{\text { Amplitude_de_Força_(Pico_a_Pico })}{\text { Amplitude_de_Deslocamento_(Pico_a_Pico })}$

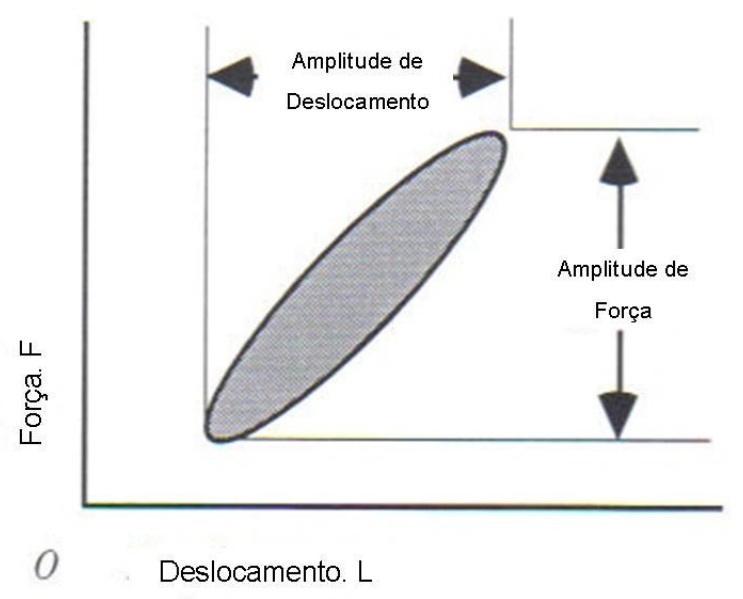

Figura 13. Histerese dinâmica. (MTS, 1993). 
Devido ao amortecimento há a dissipação da energia mecânica (W) pela conversão em calor através da deformação mecânica do coxim. A energia devido ao amortecimento é igual à área da elipse formada pela curva de histerese dinâmica mostrada nas figuras 13 e 11 e é dada conforme eq.(19).

$W=\pi \cdot F a \cdot L a \cdot \sin (\theta)$

Onde:

$\mathrm{W}=$ Energia dissipada devido ao amortecimento

$\mathrm{Fa}=$ Amplitude de força

$\mathrm{La}=$ Amplitude de deslocamento

$\Theta=$ Ângulo de fase

Na prática, utiliza-se o ângulo de fase para definir a característica de amortecimento de um coxim conforme eq.(20).

$$
\text { Fase_ }(\theta)=\sin ^{-1} \cdot\left(\frac{W}{\pi \cdot F a \cdot L a}\right)
$$

De acordo com Gade et al. (1995), Paulstra (1998) e Taylor (1986), outra maneira de interpretação do ângulo de fase é através de vetores conforme a figura 14 (Gade et al), onde $\mathrm{E}^{*}$ representa o Módulo de rigidez.

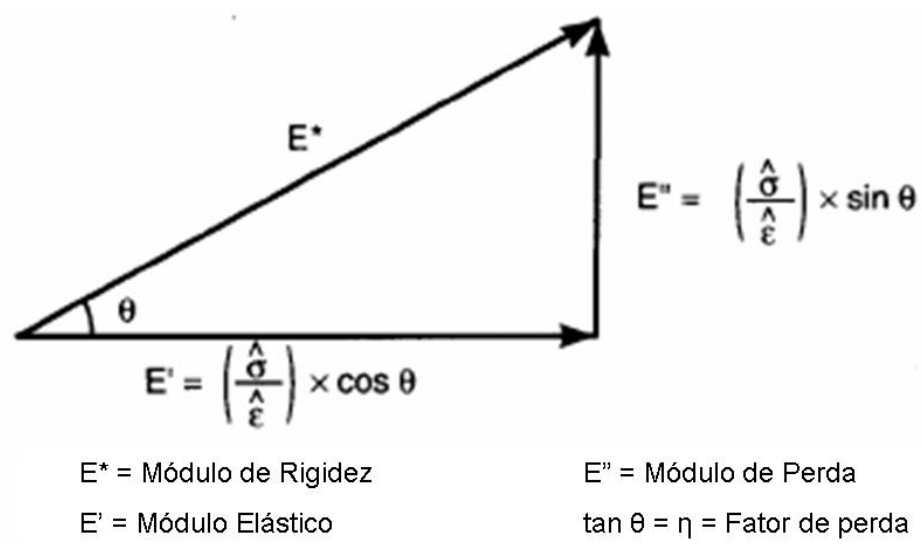

Figura 14. Representação dos módulos através de vetores (Gade et al). 
Segundo Gade et al. (1995), a maioria dos elastômeros possui amortecimento e, portanto, o deslocamento se atrasa em relação à carga aplicada ao coxim. Uma carga senoidal aplicada usualmente resulta em uma senoidal de deslocamento. O ângulo de fase entre as senóides permanece constante durante todo o ciclo de carga, mesmo podendo variar a amplitude de força e a freqüência.

$\mathrm{O}$ módulo de rigidez $\left(\mathrm{E}^{*}\right)$ pode ser obtido multiplicando a rigidez dinâmica pelo comprimento inicial do isolador e dividindo pela área da secção da transversal do mesmo, desta maneira, temos a eq.(21):

$$
E^{*}=\frac{F}{d} \times \frac{l}{A}
$$

Onde:

$\mathrm{E}^{*}=$ Módulo de rigidez.

$\mathrm{F}=$ Força.

d = Deslocamento ou deformação.

$1=$ Comprimento inicial.

$\mathrm{A}=$ Área da secção do isolador.

O módulo coincidente em fase é chamado de módulo elástico e é dado pela eq.(22):

$E^{\prime}=\frac{F}{d} \times \frac{l}{A} \times \cos \theta$

Onde:

E' = Módulo elástico.

$\mathrm{F}=$ Força aplicada.

$\mathrm{d}=$ Deslocamento ou deformação.

$1=$ Comprimento inicial.

$\mathrm{A}=$ Área da secção do isolador.

$\Theta=$ Ângulo de fase. 
Aplicando trigonometria, temos o módulo de perda, dado pela eq.(23):

$E^{\prime \prime}=\frac{F}{d} \times \frac{l}{A} \times \operatorname{sen} \theta$

Onde:

E" = Módulo de perda.

$\mathrm{F}=$ Força aplicada.

$\mathrm{d}=$ Deslocamento ou deformação.

$1=$ Comprimento inicial.

$\mathrm{A}=$ Área da secção do isolador.

$\Theta=$ Ângulo de fase.

A quantidade de plasticidade contida no material é dada pelo fator de perda ( $\eta$ ) que é dado pela razão entre o módulo de perda e o módulo elástico definido conforme eq.(24).

$$
\eta=\frac{E^{\prime \prime}}{E^{\prime}}=\tan \theta
$$

\subsection{O coxim ideal do motor}

Segundo Gogswell e Malen (1983) e Yu, Naganathan e Dukkipati (2001), para isolar a vibração na faixa de alta freqüência gerada pela força resultante do motor em trabalho, é desejável um coxim com baixa rigidez dinâmica e baixo amortecimento para que as forças transmitidas do motor para a estrutura sejam atenuadas. Isto é mostrado na figura 7 (Página 15), na qual apresenta o efeito da freqüência e do amortecimento sobre a transmissibilidade. Com o objetivo de obter uma menor transmissibilidade, a freqüência natural do sistema em certa direção deve ser menor que a freqüência excitada pela força resultante do motor em baixa rotação (marcha lenta). Desta maneira evita-se a excitação da ressonância do sistema em condições normais de uso do veículo. $\mathrm{O}$ fator de freqüência deve ser maximizado, isto significa que o coeficiente de rigidez dinâmica deve ser o mais baixo possível para se obter 
uma baixa transmissibilidade. Um baixo amortecimento também é requerido visando baixa transmissibilidade na faixa de alta freqüência.

Se a rigidez dinâmica de um coxim de motor é baixa demais, a resposta do sistema de apoio do motor pode ser problemática na faixa de baixa freqüência. Segundo Lee, Choi e Hong (1994), a faixa de baixa frequiência é representada pelo motor em marcha lenta e pelas excitações externas (acelerações e desacelerações e pela passagem em pavimentos irregulares). Dentro da faixa de baixa freqüência encontram-se os valores de frequiência de até $30 \mathrm{~Hz}$. O modo de ressonância do motor na faixa de baixa freqüência pode ser excitado por tais tipos de excitação. Valores de rigidez baixos demais proporcionarão maior deslocamento do motor conduzindo ao fim de curso (batente), podendo assim danificar os componentes do mesmo. Partindo deste princípio, alta rigidez e alto amortecimento são requeridos para minimizar os movimentos, conter a trepidação do motor e absorver a ressonância.

Através da discussão acima, pode se concluir que o sistema de apoio do motor deve suportar o peso do motor, prevenir a trepidação na faixa de baixa frequiência e isolar a vibração causada pela força resultante do motor em toda sua faixa de rotações. A faixa de rotações do motor é representada pela faixa de alta frequiência, sendo o intervalo de 30 até $200 \mathrm{~Hz}$. Para isolar a vibração na faixa de alta freqüência, o coxim do motor deve ter baixa rigidez dinâmica e baixo amortecimento.

Para prevenir a trepidação do motor na faixa de baixa freqüência, o coxim deverá ter alta rigidez e alto amortecimento. A rigidez dinâmica ideal de um coxim é mostrada na figura 15 (Yu; Naganathan; Dukkipati, 2001). A chamada baixa freqüência usualmente conduz para grandes amplitudes de deslocamento e a alta freqüência conduz para amplitudes menores de deslocamento. 


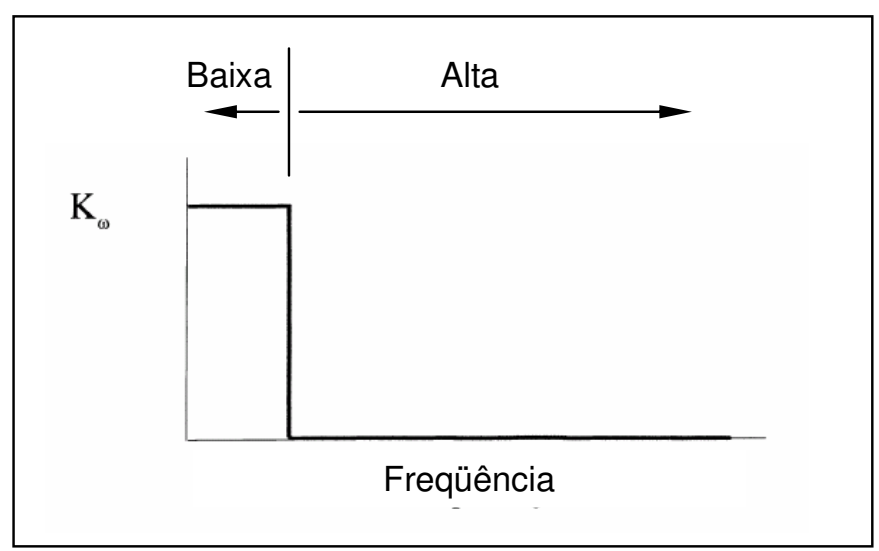

Figura 15. Rigidez dinâmica ideal de um coxim de motor (Yu; Naganathan;

Dukkipati, 2001).

Os coxins devem funcionar em um ambiente muito rigoroso tal como altas e baixas temperaturas combinadas com substâncias agressivas como óleo, gasolina e líquidos de limpeza. O custo, manutenção, confiabilidade e o tempo de vida devem ser considerados durante o projeto do coxim bem como em todo o seu sistema.

\subsection{Isoladores de borracha}

Os isoladores de borracha neste estudo serão chamados de coxins de borracha. Este tipo de coxim leva vantagens sob as molas metálicas, quando a freqüência a ser isolada não é tão baixa. Em geral, os coxins em borracha são de fácil montagem, ocupam pouco espaço e possuem um certo grau de amortecimento interno e são relativamente de baixo custo.

Barber (1992) citou que a rigidez da borracha como mola pode ser determinada em termos de módulo de rigidez dependente do material e da geometria do coxim. Através do conhecimento e experiência dos especialistas no assunto, é possível obter a rigidez desejada. A rigidez dinâmica é utilizada no projeto, em lugar da rigidez estática. A rigidez estática esta relacionada ao comportando quando ao carregamento estático (peso do motor sob o coxim) enquanto a rigidez dinâmica esta relacionada ao carregamento estático com uma amplitude de força oscilando em função da freqüência. 
Todas as borrachas possuem propriedades que variam com a temperatura. Em uma borracha com alto amortecimento, a temperatura pode aumentar devido à absorção interna de energia, portanto as propriedades devem ser estabelecidas conforme a temperatura de uso. Algumas borrachas, particularmente borracha natural, são ainda afetadas pela presença de óleo ou outros hidrocarbonetos.

Borrachas sob uma carga de compressão expandem lateralmente, portanto se deve prover o espaço (folga) necessário. Algo que previna tal movimento lateral como a colagem em uma superfície metálica tenderá a aumentar a rigidez. Entretanto, se o corpo de borracha não estiver colado, o atrito entre a face de borracha e a face da superfície de apoio atuará como limitador.

A borracha pode ser carregada em compressão, tração, cisalhamento ou com a combinação dos mesmos conforme apresentado na figura 16 (Barber, 1992). A torção pode ser considerada como uma forma de cisalhamento.

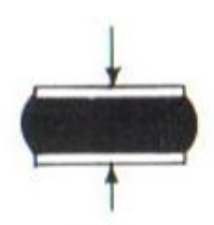

Compressão

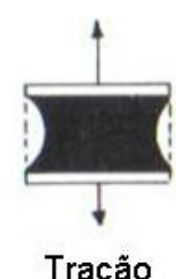

Tração

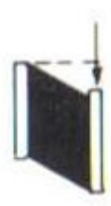

Cisalhamento
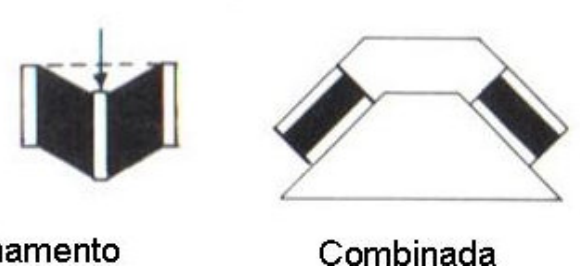

Combinada

Figura 16. Exemplos de modos de aplicação de carga sob coxins de borracha

(Barber, 1992).

Carregamento em tração é raramente utilizado exceto em aplicações leves, sendo que a integridade do coxim depende da força da colagem entre o metal e a borracha, na qual é bastante baixa (geralmente 300 a $500 \mathrm{kPa}$ ). Um corpo em forma de paralelogramo como apresentado na figura 16 , carrega a borracha uniformemente.

O calculo da rigidez da secção de um corpo de borracha não é direto como se aplicaria a uma secção metálica, devido às grandes deformações decorrentes da mudança de geometria não serem desprezíveis já que as propriedades da borracha variam conforme a pressão de carregamento. 
Conforme Karanth et al. (1996), Lindley (1978) e Rivin (1985), a borracha natural aplicada em coxins de borracha fornece o efeito mola podendo ser comparado similarmente ao efeito do aço mola em molas metálicas. Estes dois materiais não são exclusivos em seus grupos, mas eles são amplamente utilizados, particularmente onde se requer alta durabilidade em ambientes extremamente agressivos. As principais razões para o sucesso da borracha natural como mola de borracha pode ser sumariado abaixo:

- Excelente resistência à fadiga, cortes e rasgamento;

- Altamente elástica;

- Baixa geração de calor;

- Eficiente adesão a metais;

- Fabricação fácil e de baixo custo;

- Trabalha em uma ampla faixa de temperatura.

Comparado com as molas metálicas:

- A borracha dissipa energia (possui amortecimento interno);

- Molas elastoméricas não requerem manutenção;

- Pode ser facilmente projetada para oferecer diferente rigidez em diferentes direções e também oferecem características não lineares de carga-deformação;

- Pode acomodar certa quantidade de desalinhamento e são fáceis de instalar;

- Embora a borracha natural seja altamente elástica, a pequena quantidade de histerese serve para amortecer o perigo da vibração de ressonância. 


\subsection{Típicos coxins do motor}

\subsubsection{Coxim elastomérico}

Estaremos chamando de coxim elastomérico (convencional), o coxim que é basicamente constituído de borracha. Os coxins elastoméricos têm sido aplicados para isolar a estrutura do veículo da vibração do motor desde os anos 30. Desde então, muitos avanços foram realizados para melhorar seu desempenho.

O coxim elastomérico pode ser projetado visando as características necessárias de rigidez elástica em todas as direções para a apropriada isolação de vibração. Eles são compactos, de baixo custo e isentos de manutenção. Os coxins elastoméricos são conhecidos em prover alto desempenho e vida longa. O coxim elastomérico pode ser representado através do modelo mecânico abaixo na qual consiste de uma mola e um amortecedor viscoso como mostrado na figura 17 (Yu; Naganathan; Dukkipati, 2001).

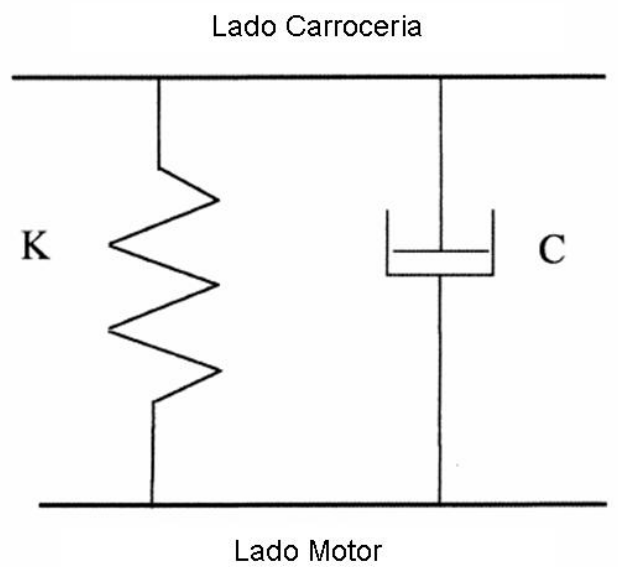

Figura 17. Modelo mecânico para o coxim elastomérico (Yu; Naganathan; Dukkipati, 2001).

A figura 18 (Swanson, 1993) ilustra a rigidez dinâmica de um coxim elastomérico que será maior em alta frequiência do que em baixa freqüência devido ao seu amortecimento. Esta característica dificulta o projeto de um sistema de coxins que 
satisfaça todos os requisitos. A alta rigidez ou o alto amortecimento do coxim elastomérico pode produzir um baixo nível de trepidação em baixa frequiência, mas seu desempenho em alta freqüência pode ser degradado. Por outro lado, baixa rigidez e baixo amortecimento produzem boa isolação de vibração em alta freqüência, mas ocorrerá um alto nível de trepidação em baixa frequiência. O objetivo é obter o melhor compromisso entre a isolação de vibração e a contenção da trepidação do motor.

O coxim elastomérico oferece um bom compromisso entre a deflexão estática e a isolação de vibração. Em muitas situações esta característica dificulta o projeto de um sistema de apoio de motor que atenda a todos os requisitos.

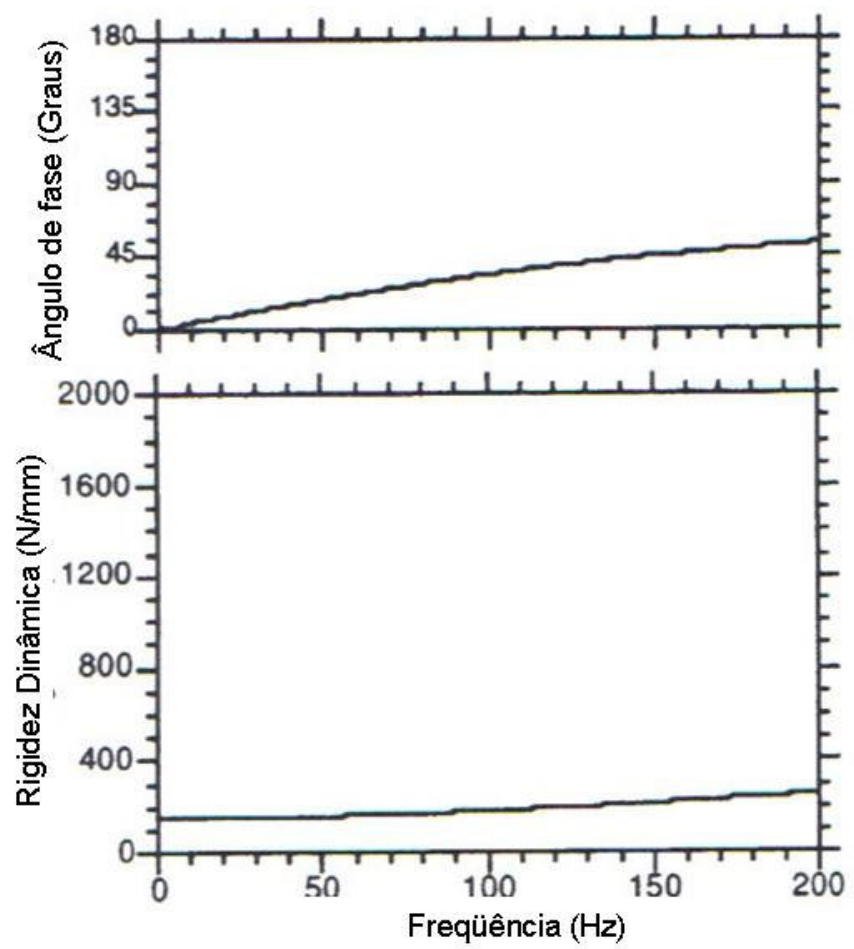

Figura 18. Rigidez dinâmica e ângulo de fase de um coxim elastomérico (Swanson, 1993).

De acordo com Yu, Naganathan e Dukkipati (2001), a aplicação do coxim elastomérico em motores automotivos tem sido sucesso durante muitos anos. Os recentes desenvolvimentos de veículos tendem a modelos pequenos, leves e com 
motores mais potentes, desta maneira há a necessidade de coxins de melhor desempenho ao invés de coxins elastoméricos. Entretanto ainda existe um substancial campo para melhoria do coxim elastomérico através do uso da rigidez não linear e características de amortecimento, isto se deve à flexibilidade de evoluir em modificações em sua geometria e no próprio material (borracha).

Como já foi dito, o coxim elastomérico vem sendo aplicado desde os anos 30, e desde então vem sofrendo diversas melhorias com o objetivo de atender os requisitos de isolação de vibração. O potencial de melhoria deste coxim é extremamente grande. Através de um projeto criativo, o coxim elastomérico pode prover adaptação para diferentes aplicações.

O desempenho do coxim elastomérico pode ser atingido especialmente com a utilização de uma geometria que permita a característica de carga-deformação não linear, ou seja, durante a exposição à alta rotação do motor o coxim é submetido à alta freqüência e baixa amplitude, desta maneira o coxim deve possuir uma baixa rigidez dinâmica.

Barber (1992) citou que quando submetido a baixa freqüência (9 a $11 \mathrm{~Hz}$ ) e alta amplitude, o coxim deve possuir alta rigidez e alto amortecimento para conter os movimentos do motor. Para conter tal movimento, o coxim elastomérico pode ser provido com batentes nos três eixos de modo a aumentar a rigidez e conseqüentemente, limitar os movimentos do motor.

Os coxins elastoméricos desenvolvidos até os anos 70 possuíam geometria extremamente simples e rudimentar com formatos cilíndricos, retangulares, etc. Conforme podemos identificar na figura 19. A construção destes coxins se limitava a duas placas metálicas com um volume de borracha vulcanizada entre elas. Antes da vulcanização, as placas recebem uma camada de adesivo responsável em promover a adesão da borracha, tal processo de adesão é concluído junto ao processo de vulcanização. 

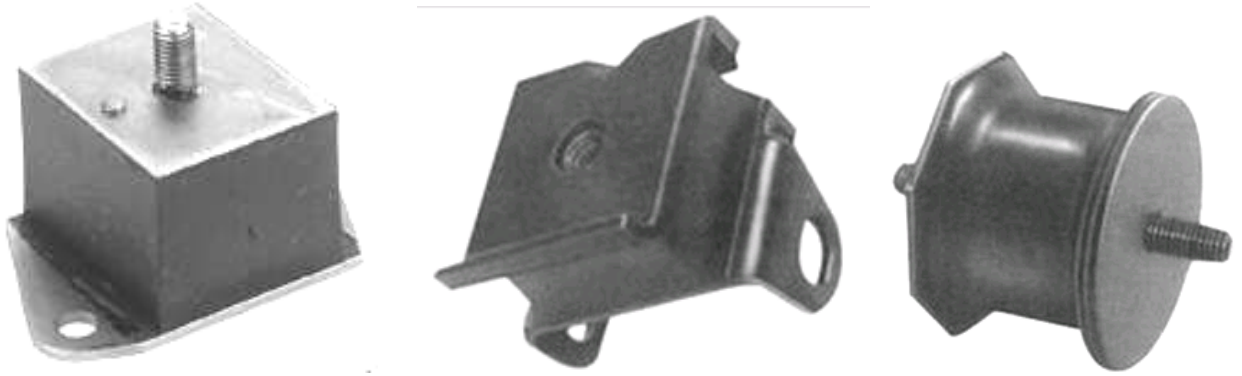

Figura 19. Exemplos de coxins elastoméricos da década de 70.

O coxim dos anos 70 possui alta rigidez estática com o objetivo de limitar os movimentos, a figura 20 mostra que a rigidez estática do coxim é praticamente constante em toda a faixa de deslocamento do motor. Devido à ausência de batentes é necessária alta dureza da borracha para permitir melhor desempenho em durabilidade e em baixas freqüências onde há maior amplitude de deslocamento, porém, quando submetido à alta rotação (alta freqüência), o desempenho pode ser degradado devido alta rigidez dinâmica conduzida pela alta rigidez estática do coxim.

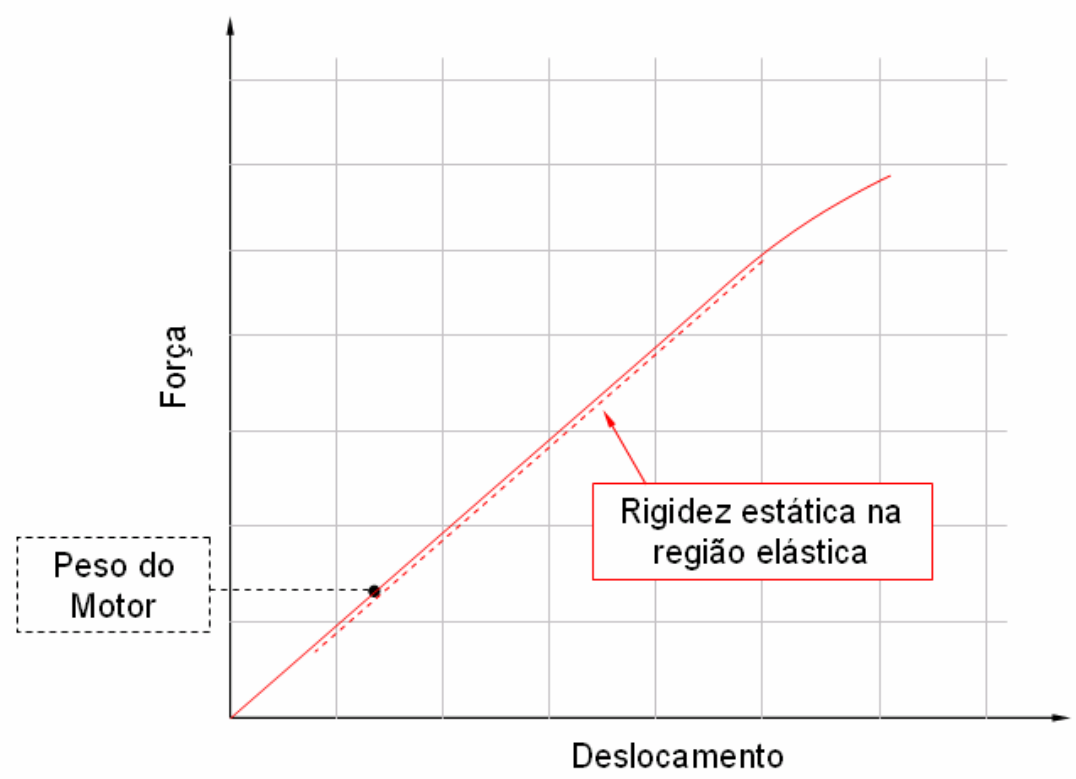

Figura 20. Curva de rigidez estática do coxim elastomérico dos anos 70. 
Os coxins elastoméricos dos anos 90, conforme figura 21, possuem a geometria formada basicamente de duas molas de borracha dispostas simetricamente em dado ângulo sob um inserto que é usualmente o elo de fixação junto ao motor. Nestes coxins destaca-se a presença de batentes incorporados nas direções vertical e horizontal.
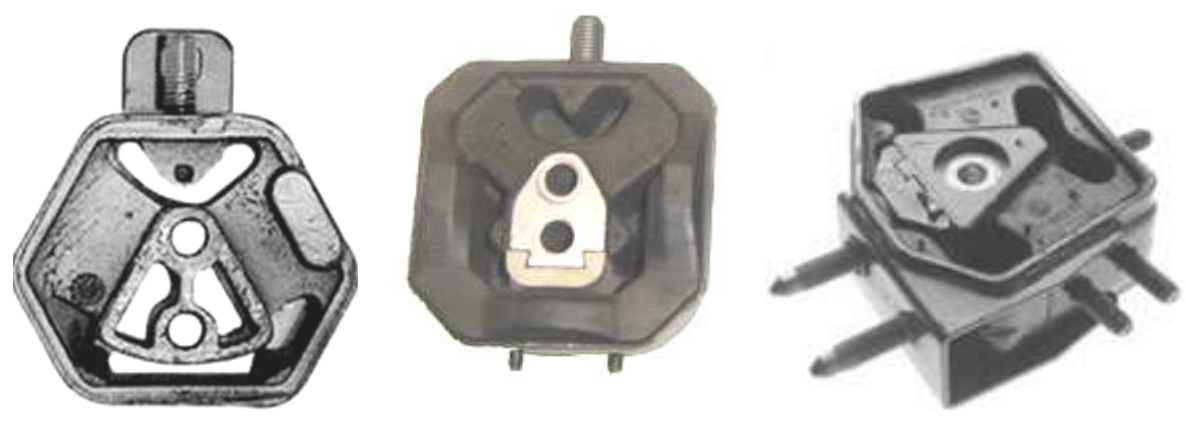

Figura 21. Exemplos de coxins elastoméricos da década de 90.

Para o bom desempenho do coxim elastomérico é desejável baixa rigidez dinâmica na faixa de alta freqüência, porém para atender este requisito, deve-se também levar em consideração o fator de amortecimento e a própria faixa de frequiência em que o coxim estará submetido, tendo como variáveis o composto de borracha e própria geometria do coxim.

A figura 22 mostra uma típica curva carga-deformação de um coxim dos anos 90 . Neste modelo temos o peso do motor apoiado sob um ponto junto à reta de rigidez estática onde ocorre à atuação da amplitude de força $(\mathrm{Fa})$ quando em regime dinâmico. Tangente a este ponto também há menor rigidez estática, o que favorece a menor rigidez dinâmica. 


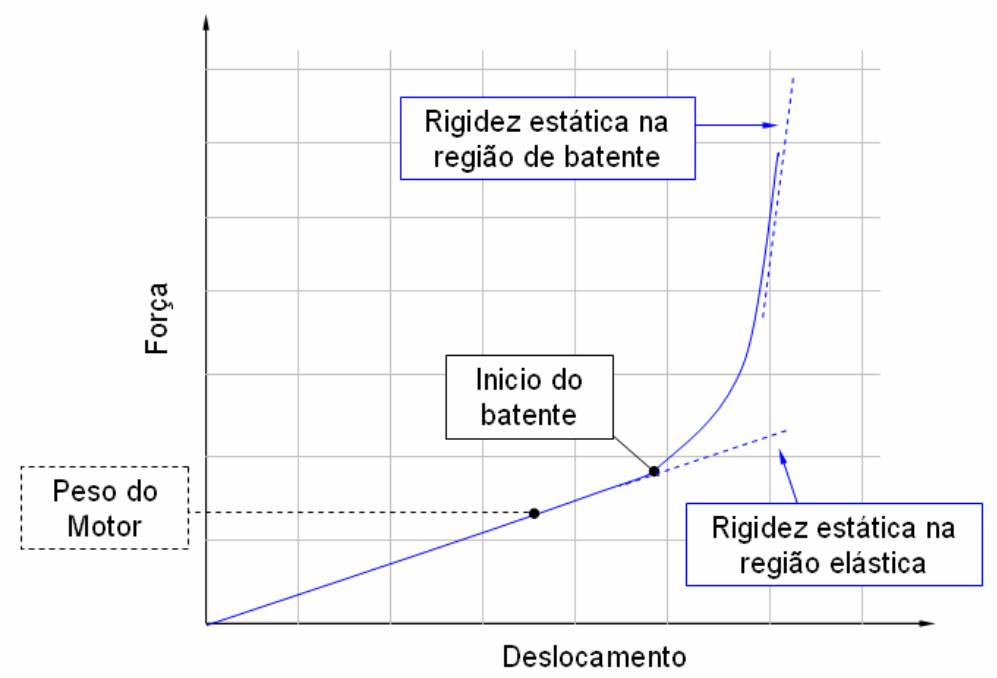

Figura 22. Curva de rigidez estática do coxim elastomérico dos anos 90.

Em baixa freqüência, temos maior amplitude de força e conseqüentemente maior amplitude de deslocamento que pode chegar até os batentes onde a rigidez estática aumenta e limita os movimentos do motor. Os batentes podem assumir vários formatos de modo a graduar o aumento da rigidez, tornando o fim de curso suave ou brusco conforme desejado.

O processo de fabricação do coxim elastomérico pode ser prensagem ou injeção, ambos os processos demandam um molde onde as ferragens e os insertos recebem por pintura uma camada de adesivo e posteriormente são inseridos no molde. No processo injetado, tem-se o fechamento do molde e posteriormente a injeção da borracha enquanto no processo prensado, coloca-se um corpo de borracha em cada cavidade e posteriormente o molde é fechado. A pressão e a temperatura imposta por ambos os processos fazem com que a borracha seja vulcanizada e conseqüentemente moldada conforme geometria descrita pelo molde. 


\subsubsection{Coxim hidráulico passivo}

De acordo com Yu, Naganathan e Dukkipati, (2001), em 1962, Richard Rasmussen patenteou o coxim hidráulico devido ao aumento do amortecimento na faixa de baixa freqüência como diferencial ao coxim elastomérico. $\mathrm{O}$ crescimento da popularidade do coxim hidráulico ocorreu basicamente por dois motivos:

1. O desenvolvimento dos veículos atuais tende a projetos com dimensões e peso menores e com motores mais potentes, requerendo sistemas de coxins mais sofisticados;

2. O coxim hidráulico tem evoluído dentro de recursos altamente refinados.

Todos os coxins hidráulicos relatados na literatura possuem conceitos similares, apresentando somente diferenças construtivas, segundo Swanson (1993), destacamse três tipos básicos:

- Coxim hidráulico com simples orifício;

- Coxim hidráulico com longo orifício;

- Coxim hidráulico com longo orifício e desacoplador.

Embora existam três diferentes tipos, todos eles possuem amortecimento. O modelo mais aplicado pela indústria automotiva é coxim com longo orifício e desacoplador, o alto amortecimento causado pelo longo orifício é caracterizado pelo acréscimo de amortecimento. Coxins hidráulicos com simples ou longo orifício podem ser ajustados para alto amortecimento em baixa frequiência, sendo utilizados para a redução do nível de impacto.

Neste trabalho apresentaremos os dois modelos principais de coxins hidráulicos de motor utilizados pela indústria automotiva, ou seja, o coxim hidráulico com longo orifício e o coxim hidráulico com longo orifício e desacoplador. 
Para iniciar a apresentação do coxim hidráulico, segue a figura 23 (Shangguan; Lu, 2002) que ilustra um típico coxim hidráulico com orifício longo de inércia + desacoplador. A configuração do coxim hidráulico sem o desacoplador é similar, exceto pela ausência do desacoplador e seu respectivo alojamento.

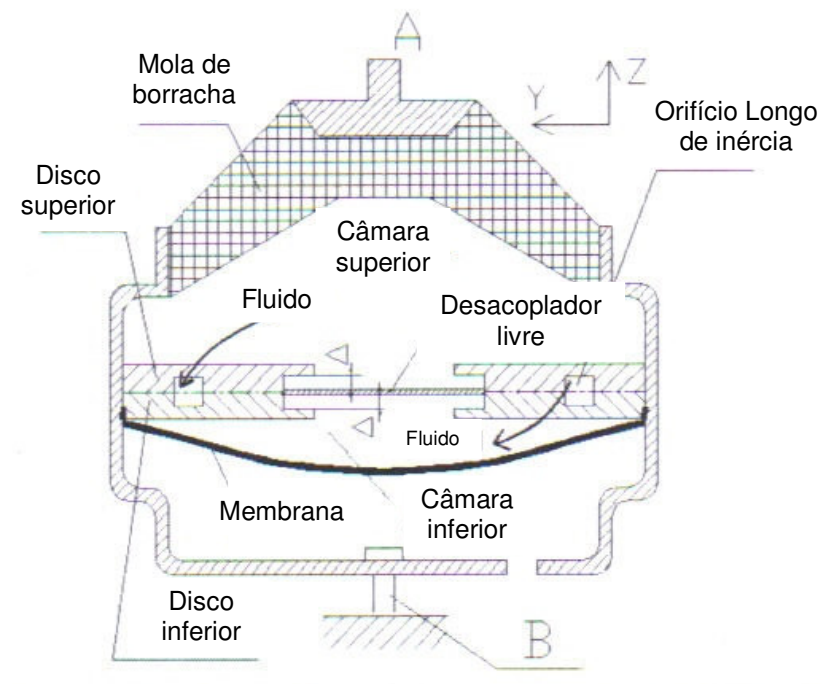

Figura 23. Típico coxim hidráulico com orifício longo de inércia e desacoplador (Shangguan; Lu, 2002).

Conforme descrito por Corcoran e Ticks (1984), Geisberger, Khajepour e Golnaraghi (2002), Shangguan e Lu (2003) e Tsujichi et al. (2003), o coxim hidráulico com orifício longo de inércia e desacoplador possui os seguintes componentes com as respectivas funções:

- Câmara superior e inferior para permitir a transferência do fluido;

- Mola de borracha. Assim como no coxim elastomérico, a mola de borracha tem por função suportar o peso do motor e no coxim hidráulico ainda atua como pistão bombeando o fluido entre as câmaras;

- Disco inferior e superior. Estes discos montados definem as seguintes funções: dividem a câmara superior da inferior, formam o longo orifício (de forma espiral) de 
inércia onde se tem a passagem do fluido responsável pela geração de amortecimento e também formam o alojamento do desacoplador;

- Fluido. O fluido é o agente responsável pela geração do amortecimento. O fluido comumente utilizado é uma mistura de água com etileno glicol;

- Membrana. Com o coxim em funcionamento, se tem o deslocamento de fluido entre as câmaras, a função da membrana é deformar de modo a permitir o aumento e a diminuição do volume de fluido na câmara inferior;

- Desacoplador. O desacoplador consiste de um disco de borracha alojado entre os discos inferior e superior. A função do desacoplador é vibrar junto à faixa de alta freqüência para obter-se redução da rigidez dinâmica agindo como "by-pass" do amortecimento.

A figura 24 (Taylor Jr., 1986) apresenta o modelo mecânico do coxim hidráulico com longo orifício de inércia e desacoplador.

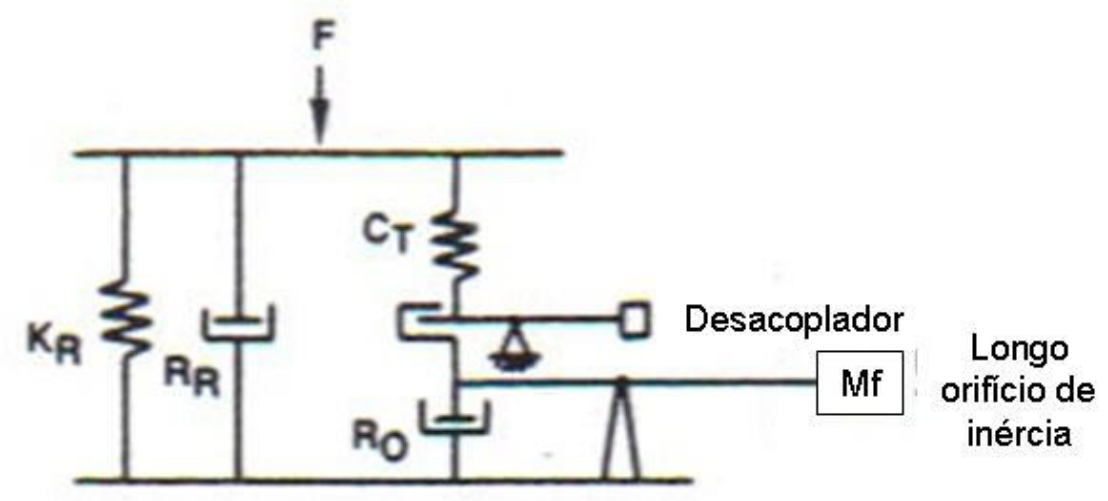

Figura 24. Modelo mecânico para o coxim hidráulico com longo orifício de inércia e desacoplador (Taylor Jr., 1986). 
Neste modelo temos que:

$\mathrm{F}=$ Força

$\mathrm{Kr}=$ Rigidez da secção de borracha

$\mathrm{Rr}=$ Amortecimento gerado pela borracha

$\mathrm{Ct}=$ Rigidez volumétrica gerada pelo fluido

Ro $=$ Amortecimento gerado pelo fluido

Mf = Massa de fluido deslocada

Conforme Kim e Singh (1995), Muller et al. (1996), Muzechuk (1984) e Swanson (1993), o coxim hidráulico opera da seguinte maneira: em baixa frequiência o fluido passa livremente entre as câmaras através do longo orifício de inércia. Devido a rigidez da membrana ser desprezível, considera-se a rigidez estática do coxim igual a rigidez da mola de borracha. Como podemos observar na figura 25 (Swanson, 1993), na freqüência "notch" (fn) a massa do fluido ressona sobre a mola de borracha reduzindo a rigidez dinâmica. A massa de fluido deslocada é definida pela razão das áreas Ap/At $(\mathrm{Ap}=$ Área da mola de borracha / At = Área da secção do orifício de inércia). Conforme a freqüência aumenta, a rigidez dinâmica aumenta até o ponto máximo onde temos a frequiência de ressonância (fr), neste ponto o orifício de inércia praticamente fecha e a rigidez dinâmica é aproximadamente igual a somatória da rigidez da mola de borracha $(\mathrm{Kr})$ e da rigidez volumétrica do fluido $(\mathrm{Ct})$. 


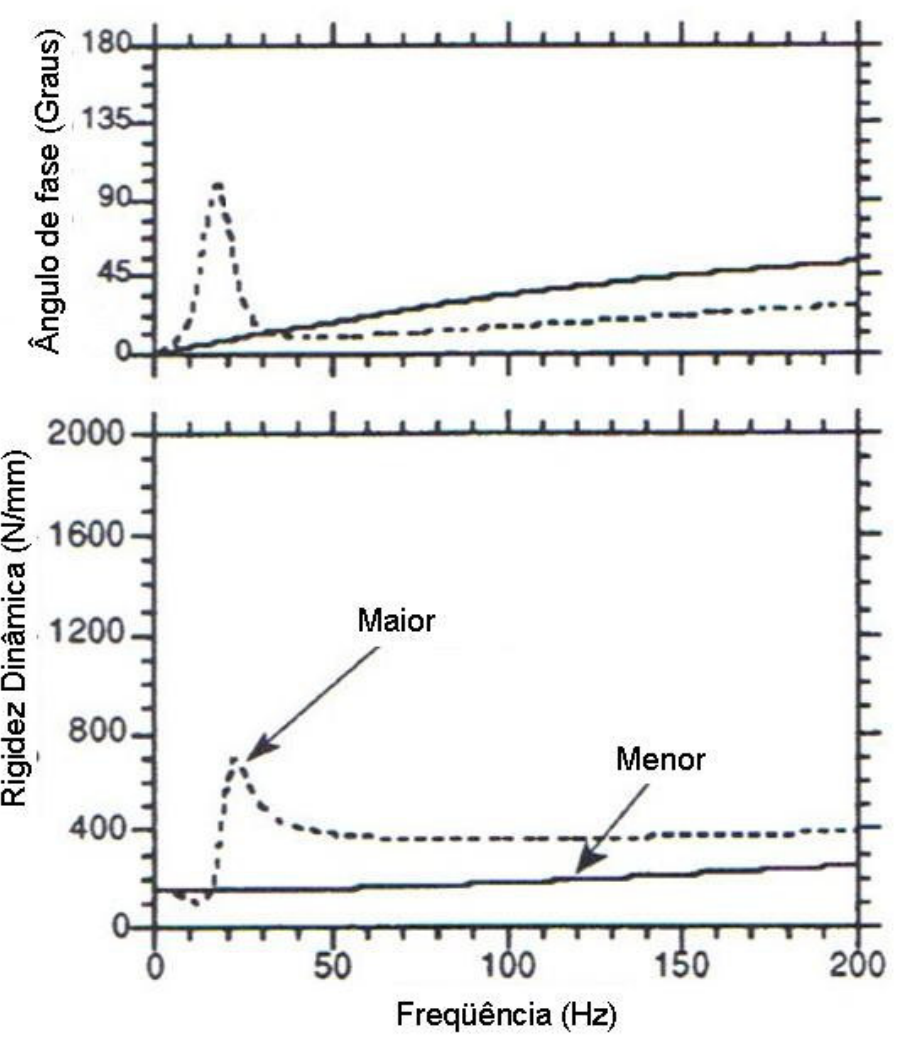

Figura 25. Comparação da rigidez dinâmica e ângulo de fase entre o coxim elastomérico (linha cheia) e coxim hidráulico com ranhura de inércia e desacoplador (linha pontilhada) (Swanson, 1993).

Este tipo de coxim hidráulico pode ser ajustado para prover excepcional isolação em uma única faixa de freqüência. O modelo mecânico apresentado na figura 24 sugere que o coxim hidráulico é similar ao coxim elastomérico com a adição de um absorvedor de vibração. Para a aplicação como coxim de motor automotivo, o coxim é ajustado para prover amortecimento adicional em uma única faixa de freqüência.

A figura 25 apresenta comparativamente o coxim hidráulico e o coxim elastomérico onde podemos observar que o ângulo de fase chega próximo a 90 graus na frequiência de ressonância (fr). Nesta freqüência, o coxim atua como amortecedor viscoso, ou simplesmente como amortecedor. Na aplicação veicular, as irregularidades do piso (baixas frequiências) geram grandes forças na direção vertical. Por este motivo, os 
coxins hidráulicos são orientados verticalmente a amortecer a trepidação do motor sobre o sistema de apoio, na qual ocorre tipicamente entre 6 e $12 \mathrm{~Hz}$.

Existe somente um problema, enquanto o coxim hidráulico promove amortecimento extra em baixa frequiência como podemos observar na figura 25, geralmente, a rigidez dinâmica de um coxim hidráulico com longo orifício de inércia e desacoplador é maior do que quando comparado ao coxim elastomérico. Apesar dos coxins hidráulicos apresentarem alto amortecimento (ângulo de fase) em baixa freqüência, eles degradam o desempenho quanto a isolação de vibração em alta freqüência. Este problema é minimizado incorporando-se o desacoplador ao coxim hidráulico.

Segundo Colgate et al. (1995) e Swanson (1993), o desacoplador funciona como um pistão flutuante de deslocamento limitado. Quando solicitado em baixa freqüência, tem-se maior amplitude de deslocamento e o pico da ação de bombeamento pressiona o desacoplador contra o fundo de seu alojamento vedando o fluxo do fluido ao seu redor. Assim todo o fluido circula livremente entre a câmara superior e inferior através do longo orifício de inércia, assumindo a condição de coxim hidráulico simples (com longo orifício de inércia), mantendo a característica de alto amortecimento em baixa freqüência.

Quando a frequiência aumenta, tem-se menor amplitude deslocamento do motor. Desta maneira o desacoplador vibra dentro de seu alojamento, reduzindo a geração de amortecimento e, conseqüentemente, reduzindo a rigidez dinâmica. $O$ desacoplador permite ao coxim hidráulico comportar-se próximo ao coxim elastomérico provendo boa isolação de vibração em toda a faixa de deslocamento.

Notamos que, mesmo com a adição do desacoplador, a redução da rigidez dinâmica ainda não supera o desempenho relativo a rigidez dinâmica do coxim elastomérico, ou seja, apesar do recurso de capacidade extra de amortecimento em baixa freqüência, o coxim elastomérico apresenta melhor desempenho quanto a isolação de vibração em alta frequiência. 
O coxim hidráulico com longo orifício de inércia não possui desacoplador bem como não possui alojamento para o mesmo, desta maneira temos que o fluido somente circula através do longo orifício em toda a faixa de frequiência.

A figura 26 (Taylor Jr., 1986) apresenta o modelo mecânico de um típico coxim hidráulico com longo orifício de inércia.

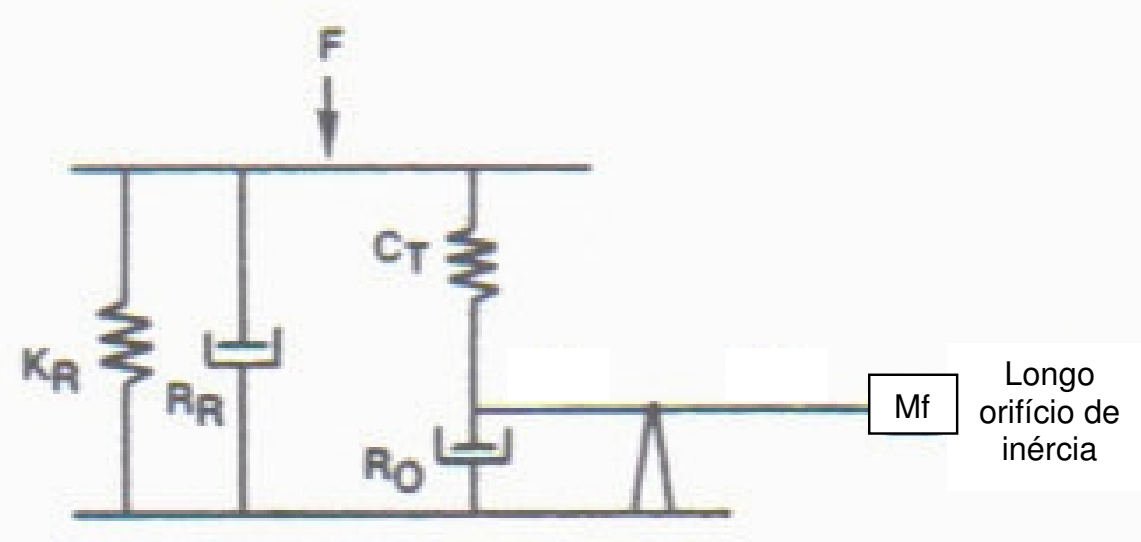

Figura 26. Modelo mecânico para o coxim hidráulico com longo orifício de inércia e desacoplador (Taylor Jr., 1986).

Neste modelo temos que:

$\mathrm{F}=$ Força

$\mathrm{Kr}=$ Rigidez da secção de borracha

$\mathrm{Rr}=$ Amortecimento gerado pela borracha

$\mathrm{Ct}=$ Rigidez volumétrica gerada pelo fluido

Ro $=$ Amortecimento gerado pelo fluido

Mf = Massa de fluido deslocada 
A figura 27 (Swanson, 1993) ilustra o comportamento dinâmico entre o coxim elastomérico e o coxim hidráulico com longo orifício de inércia.
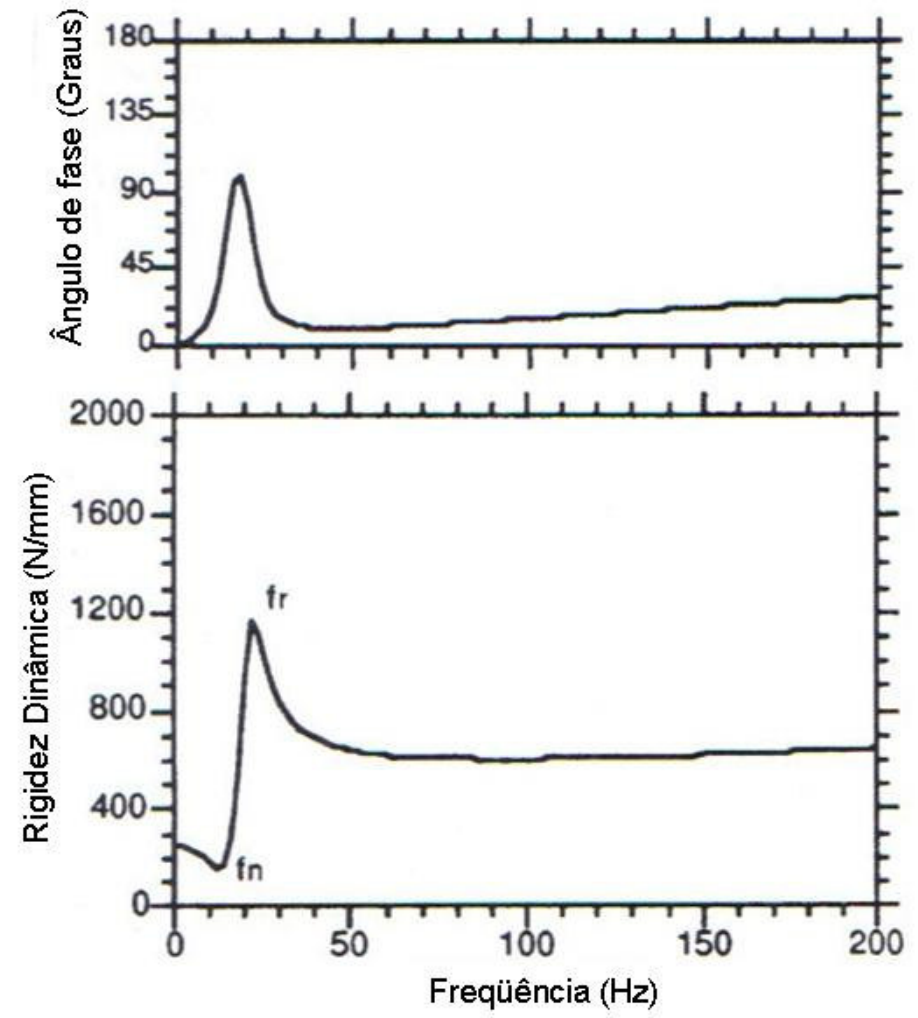

Figura 27. Rigidez dinâmica e ângulo de fase de um coxim hidráulico com longo orifício de inércia (Swanson, 1993).

A resposta dinâmica do sistema depende de parâmetros estruturais de projeto, onde o efeito do alto amortecimento em baixa frequiência é proporcional às dimensões da ranhura de inércia (secção e comprimento).

Pela condução paramétrica dos estudos de desempenho, é possível atingir uma ótima calibração do coxim hidráulico para especifíca freqüência de vibração do motor. Diversas ações tem sido conduzidas para se alcançar a otimização do projeto, como por exemplo, a seleção da rigidez dinâmica menor que a rigidez estática em determinadas freqüências. 
Da discussão anterior, pode-se concluir que o coxim hidráulico pode oferecer baixa rigidez dinâmica para isolação de vibração e alto amortecimento para controle da trepidação do motor em baixa frequiência.

A manufatura de um coxim hidráulico com orifício de inércia e desacoplador é complexa e requer maiores cuidados do que a manufatura de um coxim elastomérico. Segue abaixo os pontos que devem ser levados em consideração:

- A secção de borracha é moldada e vulcanizada através do processo de prensagem ou injeção igualmente aplicado na fabricação do coxim elastomérico, o que demanda a confecção de um molde. Porém ainda é necessária a confecção de outros dois moldes para a fabricação do desacoplador e da membrana;

- O orifício de inércia é geralmente fabricado em alumínio injetado, devemos atentar para a precisão das dimensões da ranhura de inércia onde variações indesejáveis podem comprometer o desempenho da característica de alto amortecimento;

- Durante a montagem dos componentes, o coxim é totalmente preenchido de fluido por um processo a vácuo que requer equipamentos e dispositivos especiais de alto custo pois, caso ocorra vazamento ou falha no processo de preenchimento, o coxim hidráulico perde sua característica de alto amortecimento em baixa freqüência, tornando-se um coxim elastomérico.

Todos estes fatores tornam o custo final do coxim hidráulico cerca de três vezes maior que o custo do coxim elastomérico, portanto deve-se realizar uma precisa análise de custo e benefício para justificar a aplicação do coxim hidráulico. 
Segue a tabela abaixo na qual apresenta comparativamente as características entre o coxim elastomérico e o coxim hidráulico com longo orifício de inércia e desacoplador.

\begin{tabular}{|c|c|c|}
\hline Item & Coxim Elastomérico & Coxim Hidráulico \\
\hline Ângulo de fase & Baixo & $\begin{array}{l}\text { Alto em baixa frequiência } \\
\text { prevenindo a trepidação } \\
\text { do motor }\end{array}$ \\
\hline Rigidez dinâmica & Menor & $\begin{array}{l}\text { Maior em baixa } \\
\text { frequiência e menor em } \\
\text { alta frequiência, porém } \\
\text { ainda maior do que o } \\
\text { coxim elastomérico. }\end{array}$ \\
\hline Manufatura & $\begin{array}{l}\text { Processo simples definido } \\
\text { por prensagem ou injeção }\end{array}$ & $\begin{array}{c}\text { Processo complexo } \\
\text { definido por duas etapas: } \\
\text { 1. Prensagem ou injeção. } \\
\text { 2. Enchimento de fluido } \\
\text { por um processo à vácuo. }\end{array}$ \\
\hline Componentes & Ferragens e insertos & $\begin{array}{l}\text { Ferragens, insertos, disco } \\
\text { superior e inferior, } \\
\text { desacoplador, membrana e } \\
\text { fluido. }\end{array}$ \\
\hline Custo & Baixo & $\begin{array}{c}\text { Três vezes maior do que o } \\
\text { coxim elastomérico }\end{array}$ \\
\hline
\end{tabular}

Tabela 2. Quadro comparativo entre coxim elastomérico e coxim hidráulico. 


\section{ESTUDO DE CASO}

Neste estudo de caso iremos comparar as diferentes características entre um coxim hidráulico e um coxim elastomérico, ambos desenvolvidos para a mesma aplicação.

Um veículo possui normalmente entre 3 ou 4 coxins de motor, conforme exemplo ilustrado na figura 28. Para iniciar as atividades de comparação, foi selecionado o coxim do lado esquerdo por ser um coxim hidráulico com longo orifício de inércia e partimos para a construção de um coxim elastomérico protótipo compatível à mesma aplicação. A ação inicial foi adequar os diagramas carga-deformação (rigidez estática) conforme os requisitos igualmente especificados para o coxim hidráulico.

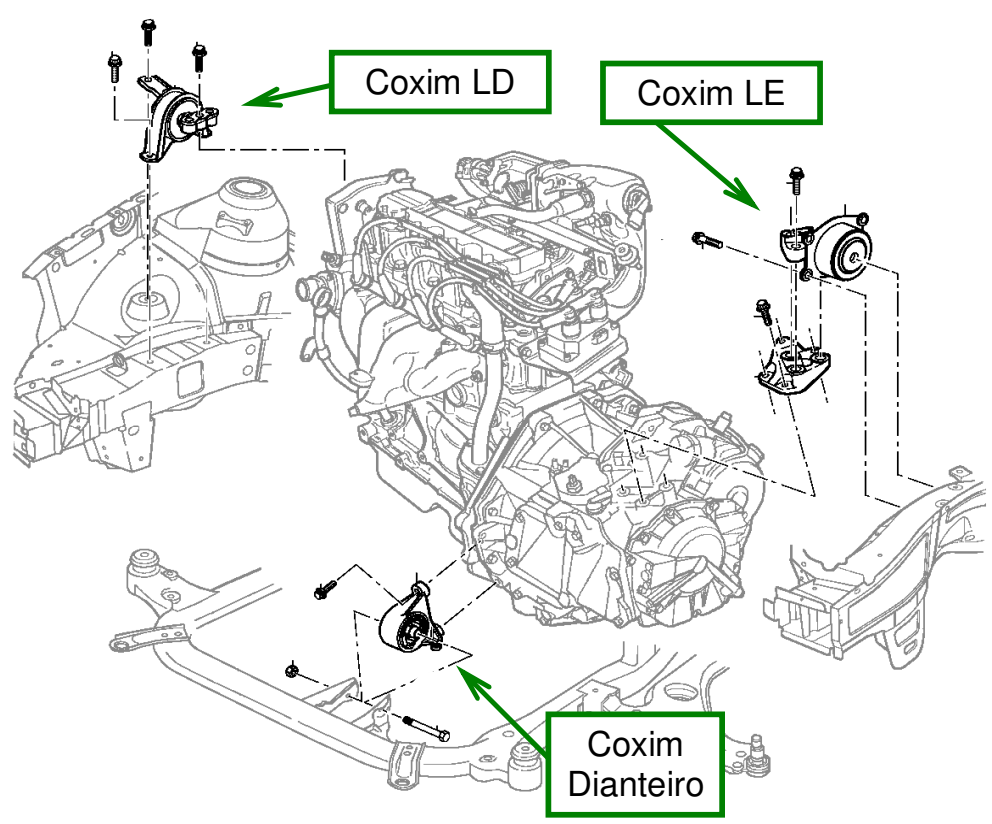

Figura 28. Disposição dos coxins de motor.

Para fabricar o coxim elastomérico, foram envolvidos alguns fabricantes de coxins para auxiliar no desenvolvimento e na realização dos ensaios requeridos. 
O equipamento utilizado é um equipamento servo-hidráulico de precisão onde temos a aplicação de carga e deslocamento sob um eixo axial. Conforme a figura 29 (MTS, 2005), o equipamento é basicamente composto de:

- Unidade de carga com um atuador hidráulico instalado sob um cabeçote de movimento axial sendo que este atuador é alimentado por uma unidade hidráulica. A unidade de carga ainda possui uma célula de carga instalada sob a mesa onde o componente a ser avaliado é instalado;

- Unidade de controle com dois canais (força e deslocamento), constituída pelo gerenciador que é responsável pela interface com o usuário bem como o gerenciamento dos softwares necessários à execução dos ensaios, e também pelo controlador digital responsável pela geração das funções, aquisição de dados, gerenciamento de sinais e controle da servo-válvula.

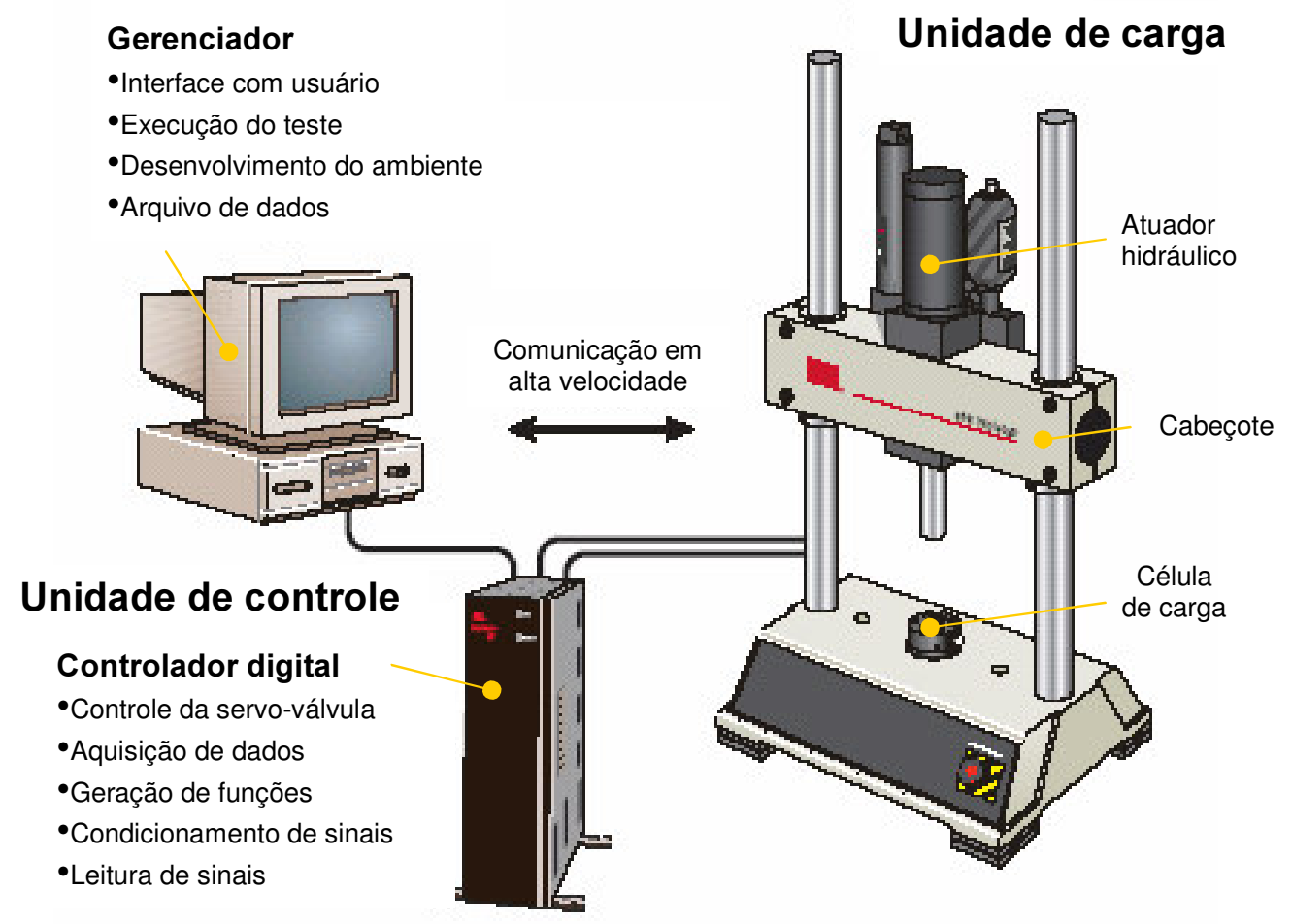

Figura 29. Equipamento servo-hidráulico (MTS, 2005). 
Este equipamento permite a avaliação de materiais e componentes elastoméricos, isto inclui coxins de motor, buchas, suporte de escapamentos, etc. Com aplicações de carga em tração, compressão e cisalhamento. A Figura 30 apresenta a unidade de carga utilizada nos ensaios. Neste equipamento foi realizado o ensaio de caracterização dinâmica, deflexão estática (diagrama carga-deformação) e durabilidade (ciclagem). Ainda a figura 30 ilustra um coxim hidráulico instalado por um dispositivo adaptador junto a unidade de carga.

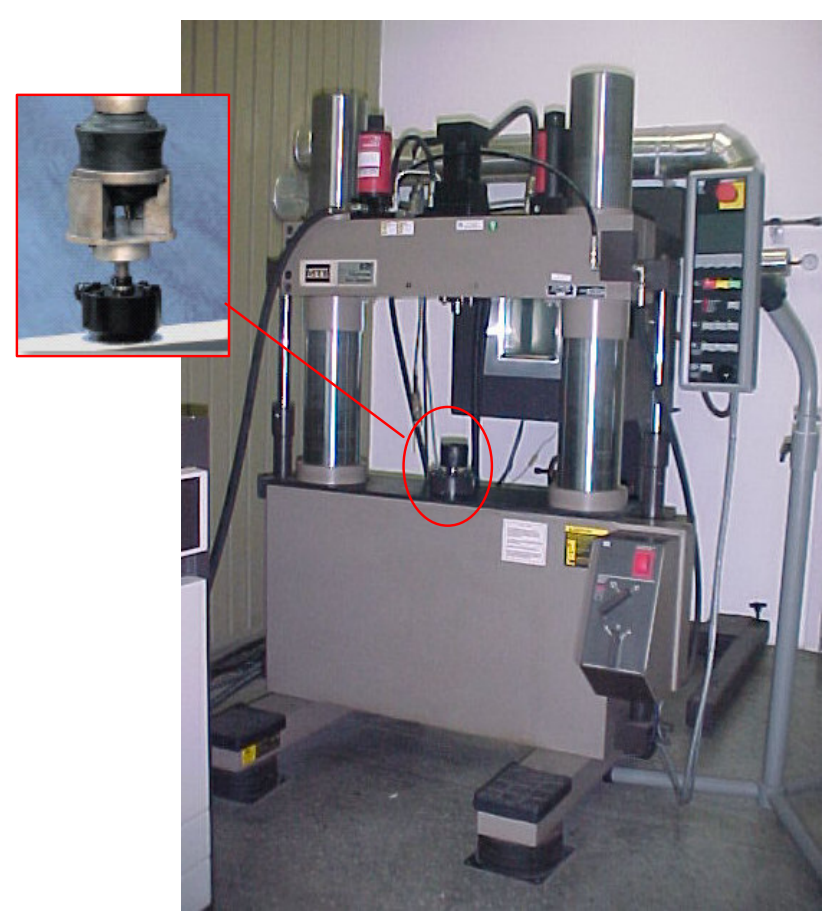

Figura 30. Unidade de carga utilizada na realização dos ensaios.

O equipamento de teste tem como desvio permissível:

- Medição de Força: $\pm 1,5 \%$.

- Medição de Deslocamento: $\pm 0,05$ mm.

- Velocidade: $\pm 10 \%$.

O coxim elastomérico foi submetido às mesmas especificações requeridas ao coxim hidráulico (desenho do produto). Para melhor apresentação dos resultados, este estudo foi divido em duas etapas sendo: característica estática e características dinâmicas. 


\subsection{Característica estática}

Para avaliar a característica estática de um coxim, utiliza-se o diagrama cargadeformação que possui dois objetivos:

1. Determinação da rigidez estática do coxim. O teste permite obter informações sobre o comportamento elástico do coxim;

2. Determinação da compressibilidade do coxim em acordo com sua condição e posição de instalação no veículo.

Para melhor entendimento do ensaio, segue as definições:

Sentido da carga de compressão: A carga é aplicada em uma direção (eixo) pela força $(\mathrm{F})$.

Força $(F)$ : É a força na qual o coxim é submetido e é determinada pelas condições funcionais do coxim.

Força inicial $(F v)$ : É a força aplicada somente para garantir que o ensaio ocorra sem a presença de folgas. Ela é aplicada na mesma direção da força (F) e é cerca de 1 a $2 \%$ da força máxima (Fmax).

Força máxima (Fmax): É o máximo valor da força (F) na qual o coxim é comprimido com a adição da força inicial (Fv).

Velocidade (v). É a velocidade constante na qual se move o ponto de aplicação da força $(\mathrm{F})$ na direção requerida.

Deformação (s): É o deslocamento realizado durante a aplicação da força (F). 
Deformação inicial (sv): É a deformação realizada durante a aplicação da força inicial (Fv).

Deformação $(s f)$ : É a deformação ocorrida entre o início do ciclo até o fim do terceiro ciclo.

Deformação máxima (smax): É a deformação ocorrida com a aplicação da Força máxima após o quarto ciclo.

Rigidez $[F=f(s)]$ : É a relação representada pelo diagrama carga-deformação.

Rigidez estática (Ke): É a tangente ao trecho elástico do digrama carga-deformação. A rigidez estática $(\mathrm{Ke})$ é determinada pela eq.(25):

$\mathrm{Ke}=\Delta \mathrm{F} / \Delta \mathrm{s}$

Onde

$\Delta \mathrm{F}=$ Intervalo de força.

$\Delta \mathrm{s}=$ Intervalo de deslocamento.

A amostra deve ser avaliada de acordo com as especificações contidas no desenho de produto, indicando as condições de instalação, dispositivos de ensaio, limites máximos e mínimos, etc...

Antes do teste, o peso da amostra e dos dispositivos de fixação devem ser compensados junto ao equipamento de teste, evitando influência junto a força $(F)$.

O ensaio deve ocorrer conforme descrito abaixo e conforme ilustrado na figura 31 :

1. A amostra é inicialmente submetida à força inicial $(\mathrm{Fv})$; 
2. O mostrador da força é ajustado para $\mathrm{F}=0$ e o mostrador para a deformação também é ajustado para $\mathrm{s}=0$;

3. Aplica-se a força (F) até a força máxima (Fmax) com a velocidade (v).

4. Retorna-se até $\mathrm{F}=0$ com a mesma velocidade (v).

5. Este ciclo de compressão deve ocorrer quatro vezes, sendo que a coleta dos dados para construção do diagrama carga-deformação deverá ocorrer no último ciclo.

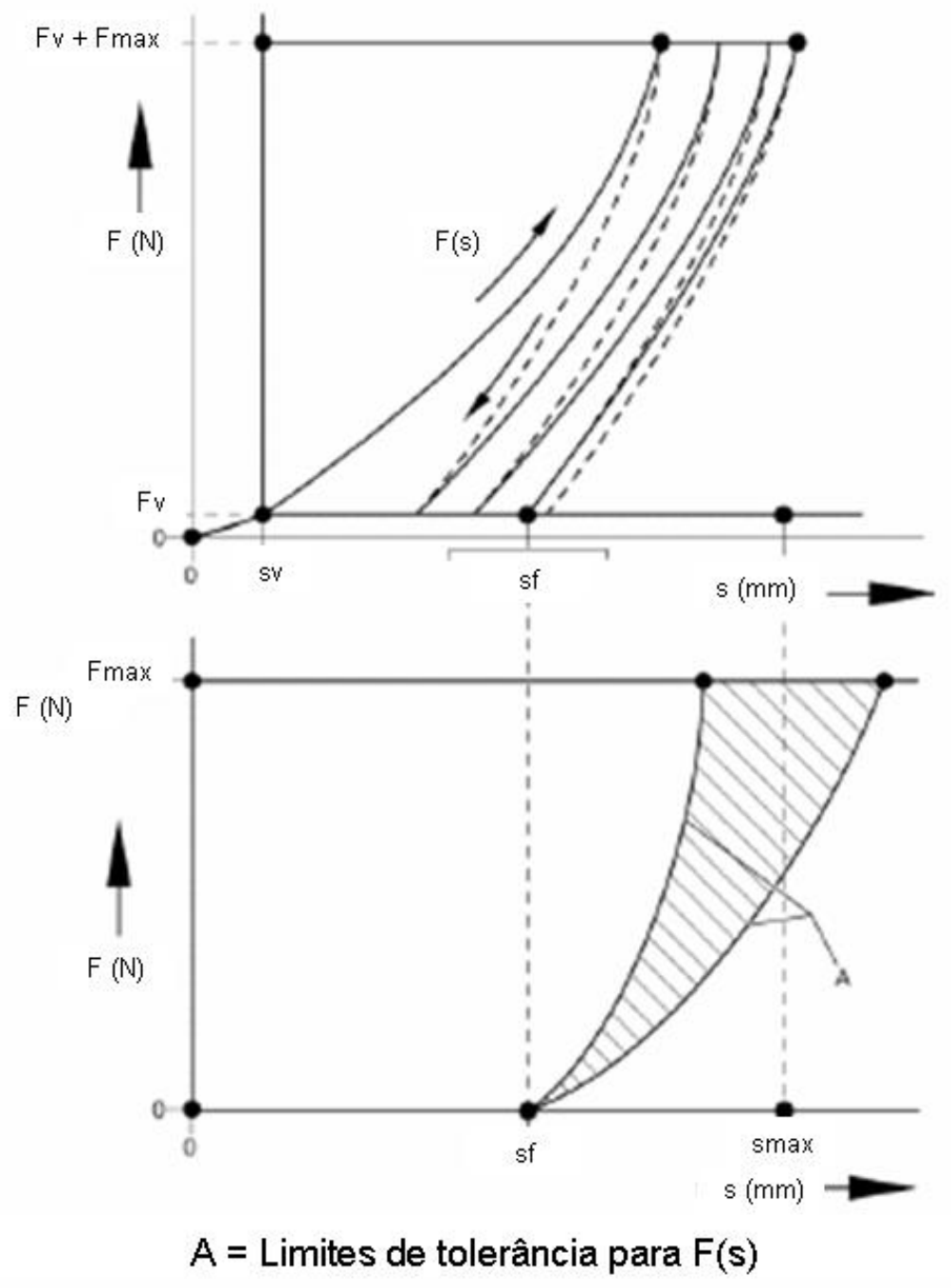

Figura 31. Procedimento para determinação do diagrama carga-deformação [F=f(s)]. 
O coxim de motor é solicitado em diversos eixos. Na prática o desenho do produto especifica o ensaio para avaliação do diagrama carga-deformação os eixos X, Y e Z dispostos conforme figura 32.

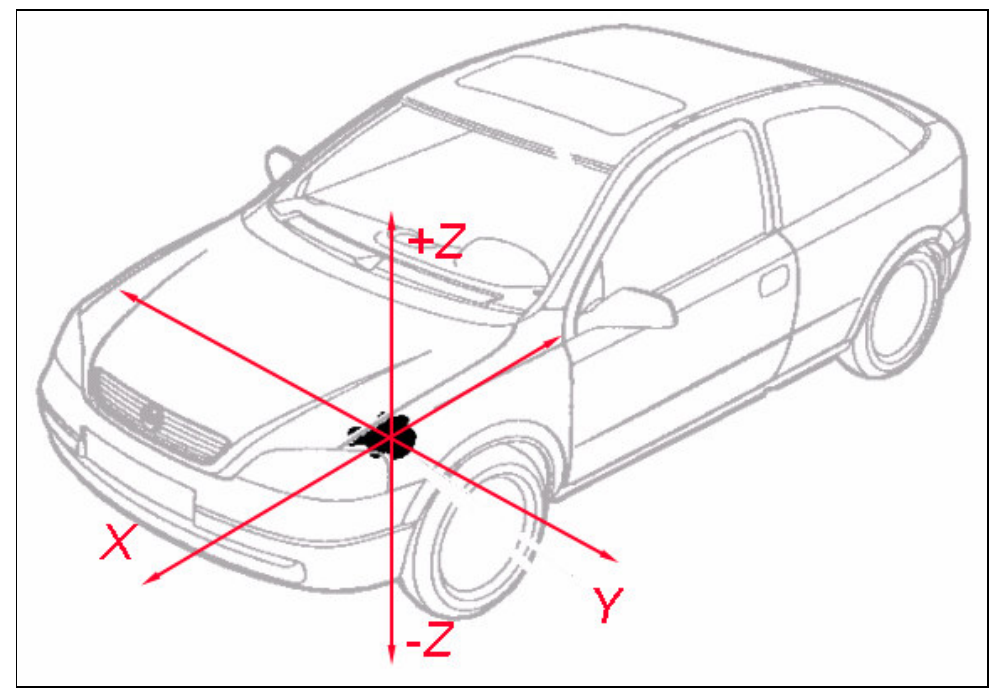

Figura 32. Indicação da direção da aplicação da força (F) através de eixos.

A figura 33 apresenta a força $(F)$ ao respectivo eixo de aplicação, sendo:

Força F1. Sentido -Z. Considerado o mais importante, pois este sentido suporta integralmente o peso do motor e oscila de acordo os movimentos verticais do motor como, por exemplo: oscilações devido a rotação do motor e oscilações devido a buracos, lombadas, etc...

Força F2. Sentido $Y$. Atua para reter o motor em movimento lateral como, por exemplo: veículo em trajetória curva.

Força F3. Sentido X. Atua para reter o motor quanto ao movimento de "para frente" e "para trás" como, por exemplo: veículo em aceleração e desaceleração (frenagem). 


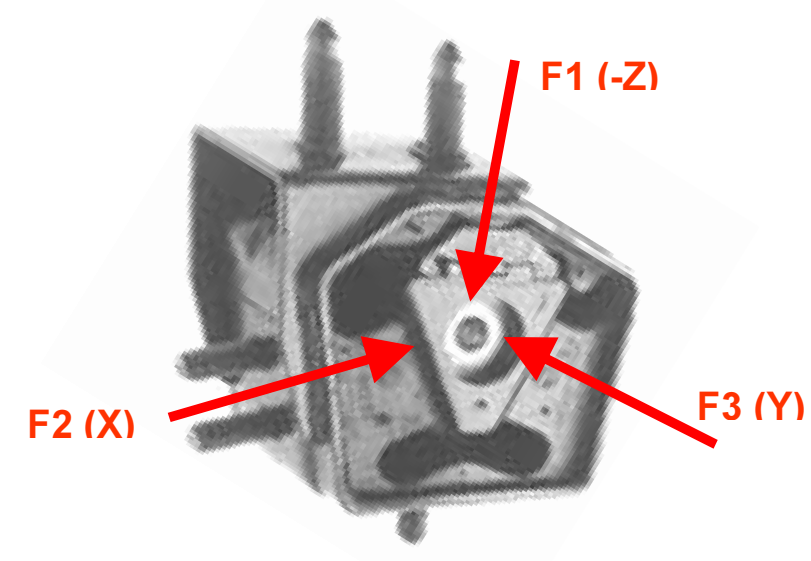

Figura 33. Força (F) aplicada sob os eixos X, Y e Z.

Este estudo de caso irá somente avaliar o digrama carga-deformação na atuação da força F1 sentido $-\mathrm{Z}$ conforme apresentado na figura 34, por tratar-se do principal ponto de aplicação de carga em um coxim.

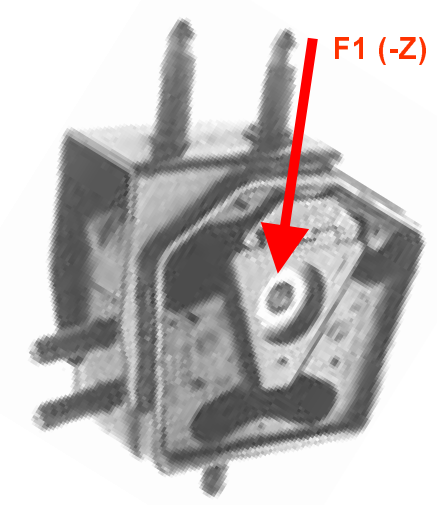

Figura 34. Aplicação da força F1 junto ao coxim.

Segue na figura 35 o diagrama carga-deformação comparando o desempenho estático entre o coxim hidráulico e coxim elastomérico, segundo os critérios descritos anteriormente. 


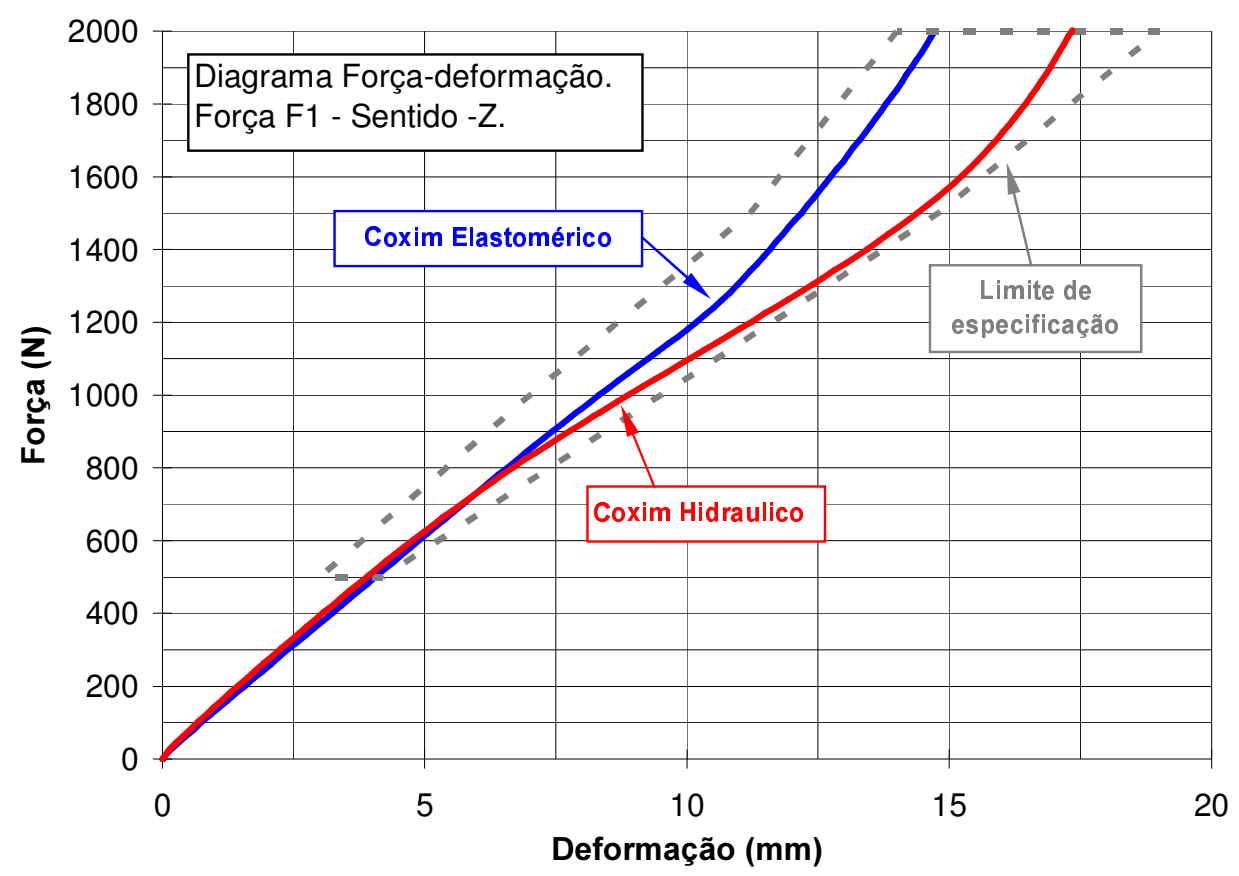

Figura 35. Diagrama carga-deformação no sentido -Z.

Conforme diagrama carga-deformação, ambos os coxins apresentaram comportamento similares no início e dentro dos limites de especificação. Conseqüentemente, ambos possuem rigidez estática dentro dos critérios requeridos.

\subsection{Características dinâmicas}

Nesta etapa, o objetivo é comparar as propriedades dinâmicas entre o coxim elastomérico e coxim hidráulico, tendo como referência a determinação da rigidez dinâmica e do ângulo de fase.

Para melhor entendimento do ensaio, segue as definições:

Pré-carga (Fm): É a força constante exercida em dada direção representando o peso do motor apoiado sob o coxim. 
Deformação estática (Lm): É a deformação do coxim decorrente do repouso até a aplicação da pré-carga (Fm) sob o mesmo eixo de referência.

Amplitude de deslocamento (La): É o valor máximo do deslocamento senoidal. O coxim é submetido a uma amplitude de deslocamento (La) sobreposto a deflexão estática (Lm). sob o mesmo eixo de aplicação da pré-carga (Fm).

Amplitude de força $(\mathrm{Fa})$. É o valor máximo da força senoidal resultante da aplicação da amplitude de deslocamento (La) sob o mesmo eixo de aplicação da pré-carga $(\mathrm{Fm})$.

Deformação (L): É o valor instantâneo da combinação das deflexões (Lm) e (La), conforme eq.(26).

$L=L m+[\operatorname{La} . \operatorname{sen}(\omega . t)]$

Força $(F)$ : É a força resultante da deformação (1) conforme eq.(27).

$F=F m+[F a \cdot \operatorname{sen}(\omega t+\theta)]$

Freqüência $(f)$ : É a freqüência da vibração senoidal dada pela velocidade angular conforme eq.(28):

$f=\frac{\omega}{2 \pi}$

Ângulo de fase $(\theta)$ : Indica o quanto a função senoidal da amplitude de deslocamento está defasada da amplitude de força. Na prática, esta é a medida da capacidade de amortecimento do coxim.

Rigidez dinâmica $(K d)$ : É a rigidez do coxim quando submetido à condição dinâmica. 
Este teste possui como referência a norma DIN 53513.

A amostra deve ser avaliada de acordo com as especificações contidas no desenho do produto indicando: as condições de instalação, dispositivos de ensaio, limites máximos e mínimos, etc.

Antes do teste, o peso da amostra e dos dispositivos de fixação devem ser compensados junto ao equipamento de teste, evitando influência junto a força (F).

O ensaio ocorre conforme a seqüência abaixo:

1. A amostra é inicialmente submetida à força inicial (Fv);

2. O mostrador da força é ajustado para $\mathrm{F}=0$ e o mostrador para a deformação também é ajustado para $1=0$;

3. Aplica-se a força $F=$ Fm e se mantém a amostra submetida sob esta condição por 6 segundos;

4. Determina-se a deformação estática (Lm);

5. Submete-se à amostra ao efeito da sobreposição da vibração senoidal de freqüência (f) constante e a uma constante amplitude de deslocamento (La). A força (Fm) deve ser mantida constante durante o período de aplicação da vibração;

6. Determina-se o ângulo de fase $(\theta)$, a amplitude de força $(\mathrm{Fa})$ e a rigidez dinâmica $(\mathrm{Kd})$. 
O ângulo de fase $(\theta)$ para uma dada frequiência é calculado através do ciclo de histerese dinâmica indicada na figura 36 (DIN 53513, 1990) e através da eq.(29):

$\theta=\operatorname{arcsen}\left[\frac{(\text { área_do_ciclo_de_histerese })}{(\pi \cdot \text { Fa.la })}\right]$

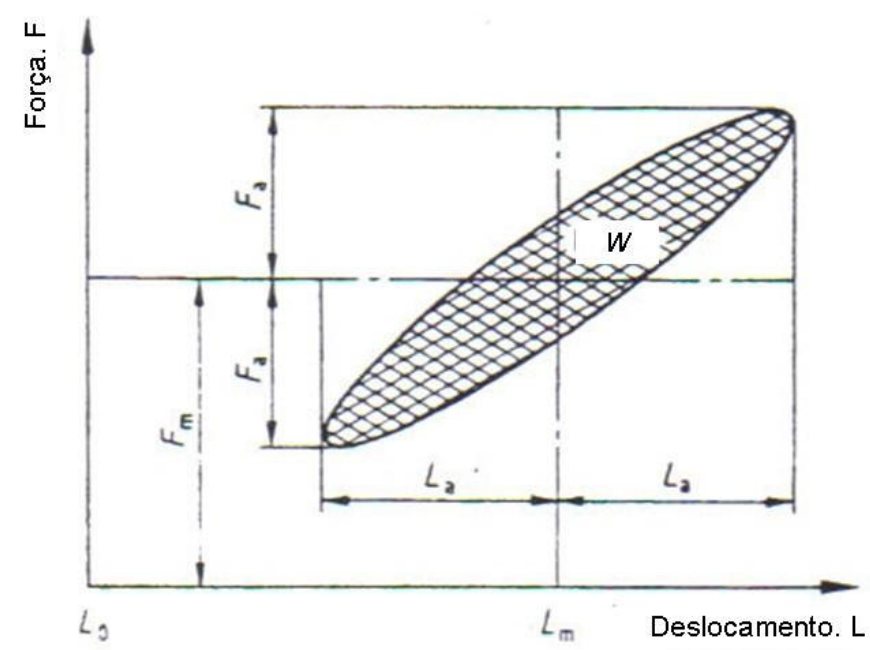

Figura 36. Representação do diagrama para determinação do ângulo de fase $(\theta)$ (DIN 53513, 1990).

A rigidez dinâmica em função da frequiência calculada através da eq.(30):

$K d=\frac{F a}{l a}$

\subsubsection{Ensaio em baixa freqüiência}

Para a realização do ensaio foram cumpridas as seguintes etapas:

1. Aplica-se a amplitude de deslocamento $\mathrm{La}= \pm 1,0 \mathrm{~mm}$ para simular a amplitude de deslocamento relativo a faixa de baixa frequiência. 
2. A amplitude de deslocamento La é aplicada ao coxim submetido a uma faixa de frequiência de excitação de 1 a $25 \mathrm{~Hz}$.

\subsubsection{Resultados do ensaio}

Segue nas figuras 37 e 38 respectivamente o comportamento do ângulo de fase e rigidez dinâmica sob esta condição:

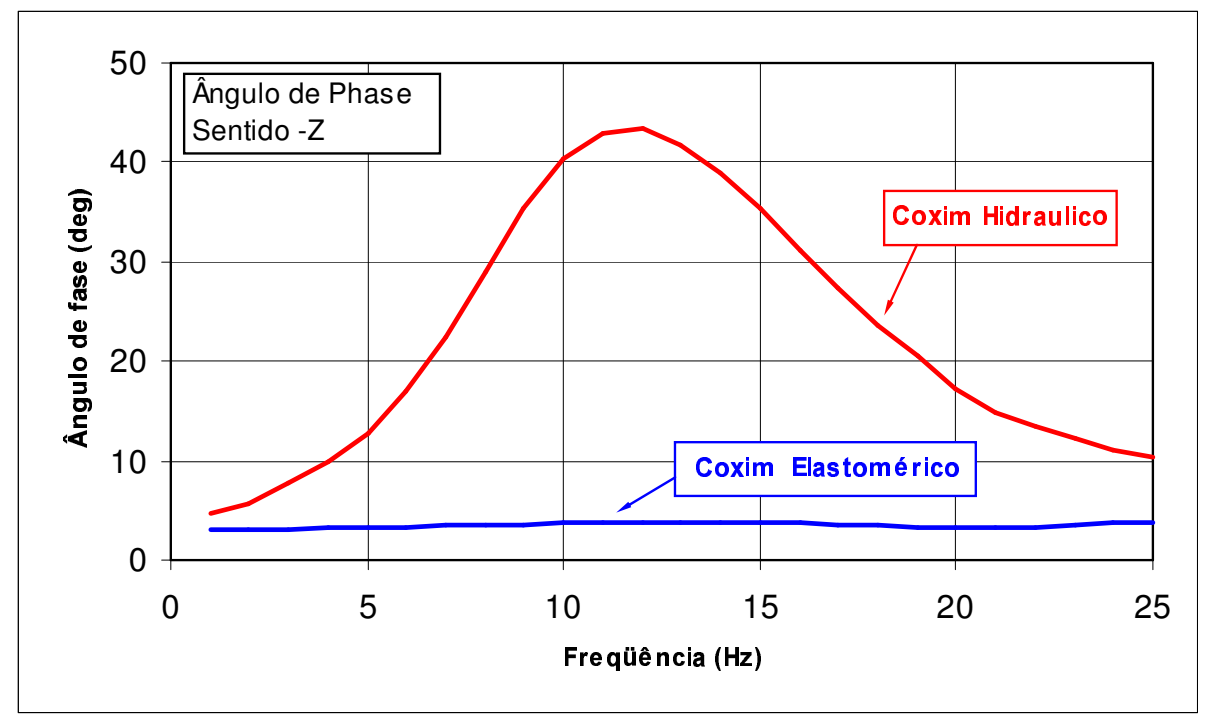

Figura 37. Ângulo de fase em função da freqüência.

O ângulo de fase é o parâmetro utilizado para caracterizar o amortecimento do coxim. O coxim hidráulico tem por propriedade um maior amortecimento em baixa freqüência conforme figura 37 . O alto amortecimento do coxim hidráulico ocorre devido a passagem do fluido através do longo orifício de inércia que conecta uma câmara a outra. Esta propriedade não existe para o coxim elastomérico, onde se verifica que o amortecimento deste modelo tende a um valor constante. 


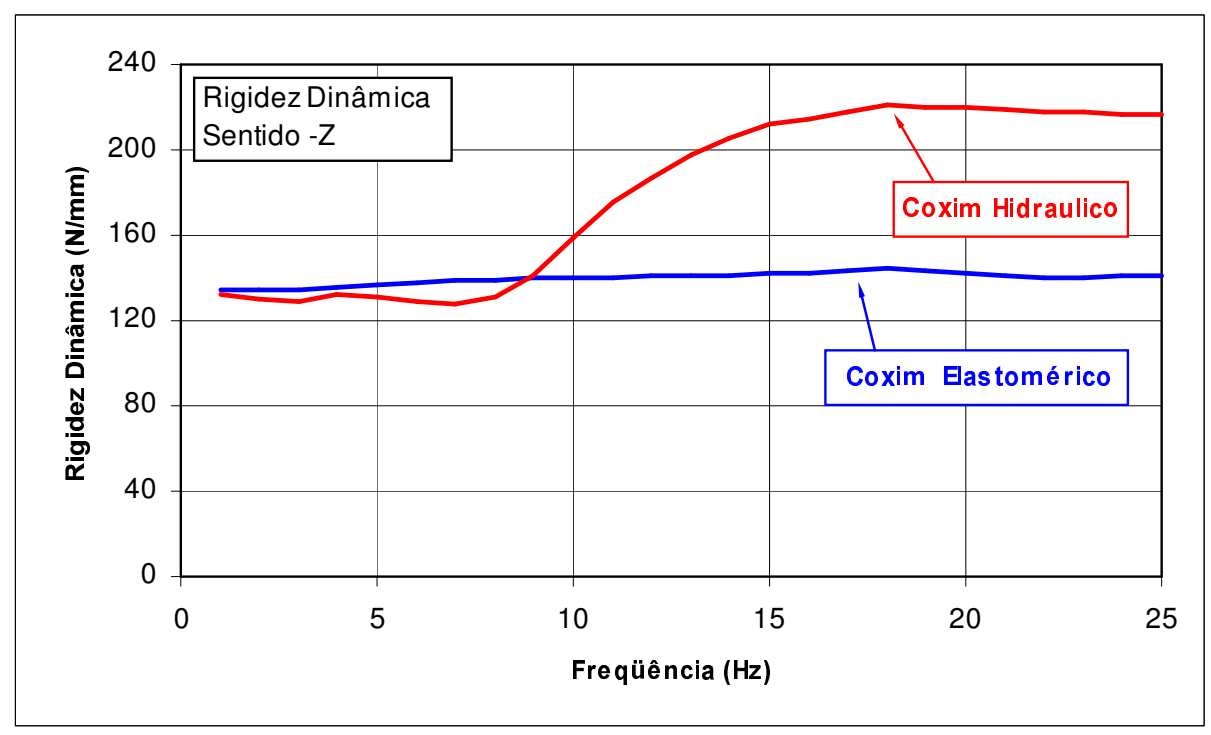

Figura 38. Rigidez dinâmica em função da freqüência.

$\mathrm{Na}$ figura 38 , observa-se que até a frequiência de $8,5 \mathrm{~Hz}$, os coxins possuem praticamente os mesmos valores de rigidez dinâmica (comportamento similar ao encontrada no diagrama carga-deformação identificado na figura 35), ou seja, até esta freqüência o fluido ainda não exerce efeito sob o coxim. Acima de $8,5 \mathrm{~Hz}$, a passagem do fluido pelo orifício promove amortecimento e, conseqüentemente, temos o acréscimo da rigidez gerada pelo fluido junto a rigidez da secção da mola de borracha do coxim.

\subsubsection{Ensaio em alta freqüência}

Para avaliar o coxim em uma faixa ampla de freqüência utiliza-se os seguintes requisitos:

1. Aplica-se a amplitude de deslocamento $\mathrm{La}= \pm 0,1 \mathrm{~mm}$ para simular a amplitude de deslocamento proveniente da faixa de alta freqüência;

2. A amplitude de deslocamento (La) é aplicado em uma faixa de frequiência entre 20 a $200 \mathrm{~Hz}$, representando rotações elevadas do motor (600 a $6000 \mathrm{rpm}$ ). 
As figuras 39 e 40 representam respectivamente o comportamento do ângulo de fase e rigidez dinâmica sob esta condição.

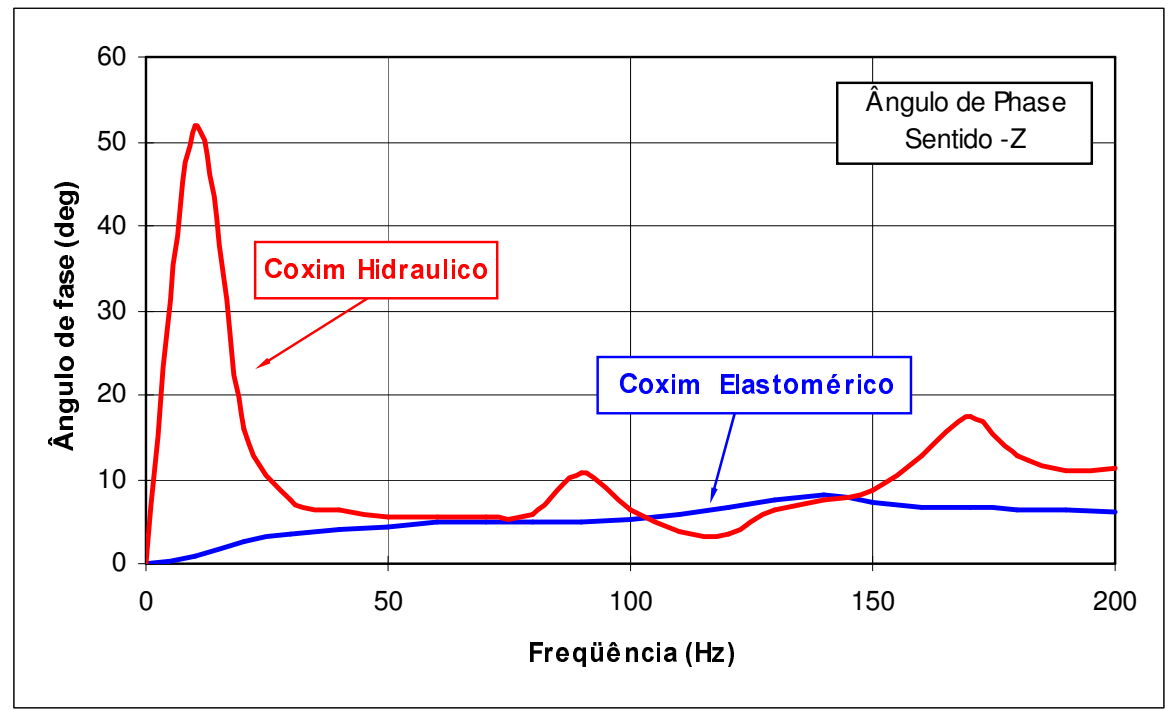

Figura 39. Ângulo de fase em função da freqüência.

Para esta condição de avaliação, conforme a figura 39, verificamos que para o coxim hidráulico o ângulo de fase é mais alto na faixa de 5 a $15 \mathrm{~Hz}$. Acima desta frequiência os valores de fase tendem a se igualarem em torno de um valor comum com variações ora para mais ora para menos. 


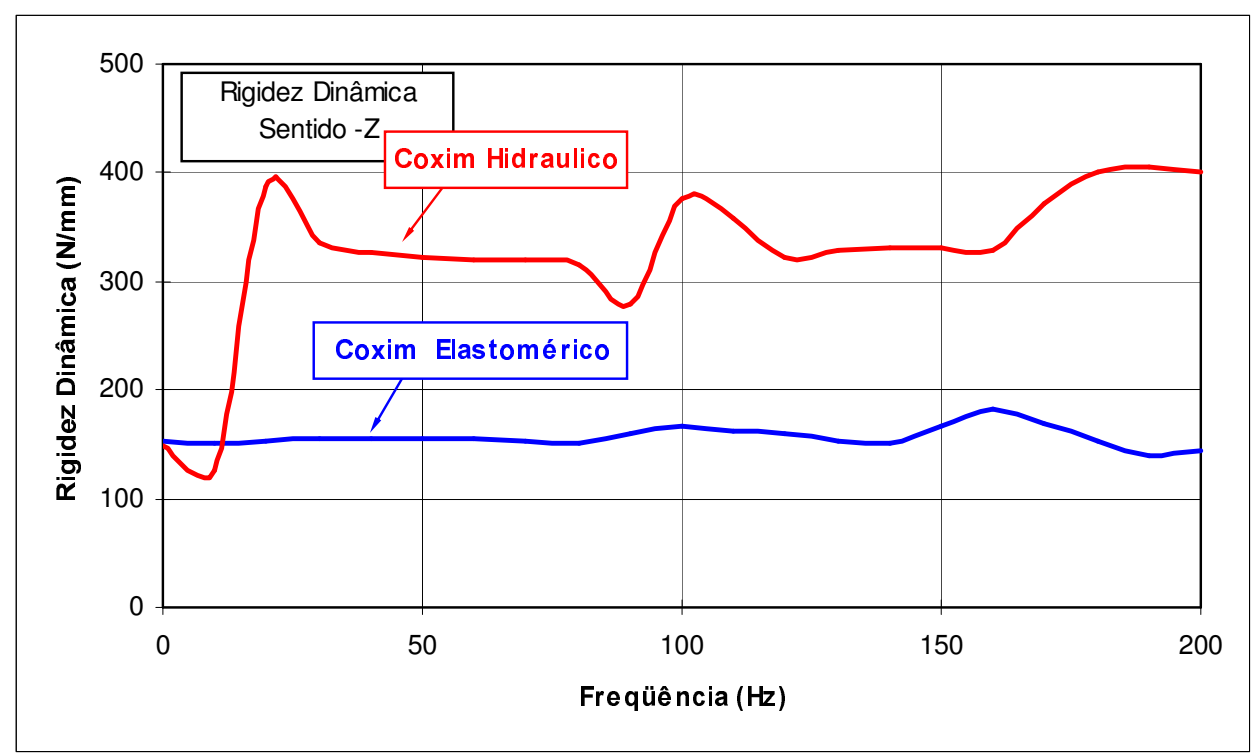

Figura 40. Rigidez dinâmica em função da freqüência.

A resposta em freqüência está relacionada com a freqüência natural do sistema $\lfloor\omega n=\sqrt{(K / M)}\rfloor$ e pelo fator de amortecimento $\lfloor\varsigma=C / 2 \sqrt{(K . M)}\rfloor$. Portanto com o aumento da rigidez do coxim hidráulico, a freqüência natural do sistema aumenta e o fator de amortecimento diminui. Desta forma a análise comparativa de desempenho quanto à isolação de vibração exige um modelo detalhado do coxim hidráulico.

Conforme apresentado na figura 39, observa-se que o pico de amortecimento medido na faixa de frequiência de 5 a $15 \mathrm{~Hz}$ provocou efeito sob a rigidez dinâmica apresentada na figura 40 , onde dentro da mesma faixa de freqüência temos um vale na freqüência chamada de freqüência "notch". Neste ponto, há somente a rigidez dinâmica da secção da mola de borracha e logo adiante observamos um pico na freqüência chamada de frequiência de ressonância. Nesta freqüência o orifício de inércia "fecha" e o pico de rigidez representa a somatória da rigidez da secção da mola de borracha e da rigidez volumétrica do fluido. Este fenômeno ocorreu também na faixa de 80 a $120 \mathrm{~Hz}$. 


\section{DISCUSSÃO E COMENTÁRIOS}

O coxim de motor ideal deve isolar a vibração originada pelas forças resultantes do desbalanceamento do motor em toda sua faixa de rotações e prevenir transmissão de vibração para a carroceria do veículo.

Conforme observamos no item 2.8 (tipos de coxins), o coxim elastomérico sofreu diversas melhorias quanto a sua geometria passando de um simples corpo de borracha nos anos 70 para um perfil modelado com batentes incorporados nos anos 90, desta maneira pode-se utilizar menor rigidez mantendo a limitação dos movimentos do motor (batentes). Apesar das melhorias, observamos que o coxim elastomérico oferece somente desempenho quanto à deflexão estática e isolação de vibração. O coxim hidráulico, por sua vez, pode prover melhor desempenho do que o coxim elastomérico especialmente na faixa de baixa freqüência, onde o coxim hidráulico apresenta maior amortecimento prevenindo a trepidação do motor. A rigidez do coxim hidráulico aumentou 2,3 vezes, alterando a frequiência de ressonância.

Além do comportamento citado acima, devemos considerar o custo dos coxins, como colocado no item 2.8, o projeto e a fabricação de um coxim elastomérico são extremamente simples quando comparados ao coxim hidráulico, onde para este modelo o projeto deve prever a geração de amortecimento em baixa freqüência. Além de conter diversos componentes, o processo de fabricação do coxim hidráulico é complexo e necessita de equipamentos especiais e precisos. Desta maneira, o custo de um coxim hidráulico pode ser três vezes maior que o custo de um coxim elastomérico.

Considerando os fatores discutidos, a escolha do tipo de coxim deve ser analisada frente a qualidade de conforto requerida pelo usuário, pois um alto investimento em determinado tipo de coxim pode refletir pouco ou até mesmo não ser perceptível ao usuário. 


\section{CONCLUSÕES}

Baseado nas experiências realizadas bem como orientado pela literatura pesquisada podemos concluir que:

Conforme apresentado na figura 35, verificamos que ambos os coxins atendem os limites de especificação do diagrama carga-deformação, ou seja, ambos os coxins são equivalentes quanto à deformação ao carregamento estático.

Em baixa freqüência, conforme figura 37, o ângulo de fase do coxim hidráulico aumenta na região entre 5 e $15 \mathrm{~Hz}$ devido ao amortecimento gerado pelo fluido com o objetivo de conter a trepidação do motor, enquanto o ângulo de fase do coxim elastomérico apresenta-se de forma praticamente constante. Quanto ao comportamento da rigidez dinâmica apresentada na figura 38, temos inicialmente valores similares, porém a partir de $7 \mathrm{~Hz}$ a rigidez do coxim hidráulico aumenta devido ao acréscimo de amortecimento gerada pelo fluido.

$\mathrm{Na}$ análise do comportamento em alta frequiência, conforme figura 39, o ângulo de fase do coxim hidráulico mantém-se alto entre 5 e $20 \mathrm{~Hz}$ (também identificado em baixa freqüência); no restante da faixa de freqüência notamos ainda que o coxim hidráulico possui ângulo de fase similar ao coxim elastomérico. Já a rigidez dinâmica do coxim hidráulico conforme apresentado na figura 40, aumenta após $10 \mathrm{~Hz}$, sendo que este acréscimo corresponde ao amortecimento do fluido que se mantém constante ao longo da faixa de freqüência. Por fim, a rigidez dinâmica do coxim hidráulico acaba por ser praticamente o dobro da rigidez dinâmica do coxim elastomérico.

O comportamento quanto a isolação de vibração irá depender da rigidez dinâmica, da constante de amortecimento, da faixa de freqüência em que o coxim estará submetido e com o uso de um modelo detalhado de ambos os coxins. 


\section{RECOMENDAÇÕES E NOVOS ESTUDOS}

Conforme apresentado, este estudo comparativo abordou o comportamento do coxim hidráulico e do coxim elastomérico considerando o efeito estático e dinâmico induzido pelo motor. Desta maneira compreendemos as características construtivas e funcionais de ambos os modelos. Este estudo servirá de apoio na escolha do tipo de coxim que irá compor o sistema de apoio do motor. Porém para a decisão final por qual tipo de coxim a ser adotado devem ser feitas avaliações juntamente com o veículo inteiro em laboratórios especializados, visando a avaliação da percepção do usuário, com o objetivo de aperfeiçoar o conforto.

O coxim hidráulico pode prover melhor desempenho especialmente em baixa freqüência prevenindo a trepidação do motor, do mesmo modo que o coxim elastomérico pode prover boa isolação de vibração em alta freqüência, mas eles não podem resolver todos os problemas inerentes que surgem durante o funcionamento do veículo. Desta maneira identificamos que técnicas ativas estão sendo desenvolvidas para melhoria do desempenho do coxim hidráulico, trazendo maiores alternativas em calibração e ajustes.

Conforme Swanson (1993), o sistema de coxins ativos do motor pode ter alta rigidez dinâmica em baixa freqüência e calibrado para ter baixa rigidez dinâmica em alta freqüência para melhor isolar a vibração. Visto que os coxins ativos usam sensores, unidades de controle e uma fonte de energia, o sistema de coxins ativos do motor aumentará peso, custo e consumo de energia. O sistema hoje ainda não é robusto suficiente para produção em série, o que reduz a confiabilidade do sistema. Requisitos como desempenho, confiabilidade e economia deste sistema ainda requerem maior aprimoramento para a sua viabilidade em produção. $\mathrm{O}$ sistema de coxins ativos do motor tem sido considerado como a próxima geração de coxins do motor. 


\section{REFERÊNCIAS BIBLIOGRÁFICAS}

BARBER, A. Handbook of noise and vibration control. 6.ed. Oxon: Elsevier, 1992. 481p. (Advanced technology).

BERNUCHON, M. A new generation of engine mounts. In: INTERNATIONAL CONGRESS AND EXPOSITION, Detroit, Michigan, 1984. Papers. Warrendale: Society of Automotive Engineers, 1984. (SAE paper, 840259).

COGSWELL, J. A.; MALEN, D. E. Engine mount for integral body vehicle. In: INTERNATIONAL CONGRESS AND EXPOSITION, Detroit, Michigan, 1983. Papers. Warrendale: Society of Automotive Engineers, 1983 (SAE paper, 830258).

COLGATE, J. E.; CHANG C. T.; CHIOU Y. C.; LIU W. K.; KEER, L. M. Modeling of hydraulic engine mount focusing on response to sinusoidal and composite excitations. Journal of Sound and Vibration, v. 184, n 3, p 503-528, jul, 1995.

CORCORAN, P. E.; TICKS G. H. Hydraulic engine mount characteristics. In: INTERNATIONAL CONGRESS AND EXPOSITION, Detroit, Michigan, 1984. Papers. Warrendale: Society of Automotive Engineers, 1984. (SAE Paper, 840407).

DEUTSCHER INSTITUTE NORMENAUSSCHUSS. DIN 53513: determination of viscoelastic properties of elastomers. s.L., 1990.

FLOWER, W. C. Updating a 30-year old concept in vibration control. In: INTERNATIONAL TRUCK AND BUS MEETING AND EXPOSITION, WinstonSalem, North Carolina, 1995. Papers. Warrendale: Society of Automotive Engineers, 1995. (SAE paper, 952666). 
GADE, S.; KAVERI, K.; KOSTANTIN-HASEN, H.; HERLUFSEN, H. Complex modulus and damping measurements using resonant and non-resonant methods. In: NOISE AND VIBRATION CONFERENCE AND EXPOSITION, Traverse City, Michigan, 1995. Papers. Warrendale: Society of Automotive Engineers, 1995. (SAE paper, 951333).

GEISBERGER, A.; KHAJEPOUR, A.; GOLNARAGHI, F. Non-linear modeling of hydraulic mounts theory and experiment. Journal of Sound and Vibration, v. 249, n.2, p. 371-397, jan, 2002.

HARTOG, J. P. D. Vibrações nos sistemas mecânicos. São Paulo: Edgard Blucher, 1972. 366p.

HARRIS, C. M.; CREDE, C. E. Shock and vibration handbook. 2 ed. New York: McGraw-Hill, 1976.

INMAN, D. J. Engineering vibration. New Jersey: Prentice Hall, 1996. 560p.

KARANTH, N. V.; RAJU S.; KUMBHAR M, S.; VIJAYALAKSHMI, M. Design and evaluation of engine mounts of a passenger utility vehicle. In: SYMPOSIUM ON INTERNATIONAL AUTOMOTIVE TECHNOLOGY, Pune, India, 1996. Papers. Warrendale: Society Automotive Engineers, 1996. (SAE paper, 962493).

KIM, G.; SINGH, R. A study of passive and adaptive hydraulic engine mount system with emphasis on non-linear characteristics. Journal of Sound and Vibration, v. 179, n. 3, p. 427-453, jun, 1995.

LEE, K. H.; CHOI, Y. T. ; HONG S. P. Performance design of hydraulic mount for low frequency engine vibration and noise control. In: INTERNATIONAL OFFHIGHWAY \& POWERPLANT CONGRESS AND EXPOSITION, Milwaukee, Wisconsin, 1994. Papers. Warrendale: Society of Automotive Engineers, 1994. (SAE paper, 941777). 
LINDLEY, P. B. Engineering design with natural rubber. 4 ed. Hertford: The Malaysia Rubber Producer's Research Association, 1978. 48p. (NR Technical Bulletins).

MTS. 790.3X Applications for TestWare-SX. Manual Part Number 150331-01A. 1993.

MÜLLER M.; WELTIN, U.; LAW, D.; ROBERTS, M.M.; SIEBLER, T.W. Engine mounts and NVH. Automotive Engineering, v.102, n.7, p.19-23, jul., 1994.

MÜLLER, M.; ECKEL H. G.; LEIBACH M. ; BORS W. Reduction of noise and vibration in vehicles by appropriate engine mount system and active absorbers. In: INTERNATIONAL CONGRESS AND EXPOSITION, Detroit, Michigan, 1996. Papers. Warrendale: Society of Automotive Engineers, 1996. (SAE paper, 960185).

MÜLLER, M.; WELTIN U.; LAW D.; ROBERTS M. M. ; SIEBLER T. W. The Effect of engine mounts on the noise and vibration behavior of vehicles. In: INTERNATIONAL CONGRESS AND EXPOSITION, Detroit, Michigan, 1994. Papers. Warrendale: Society of Automotive Engineers, 1994. (SAE paper, 940607).

MUZECHUK, R.A. Hydraulic mounts-improved engine isolation. In: INTERNATIONAL CONGRESS AND EXPOSITION, Detroit, Michigan, 1984. Papers. Warrendale: Society of Automotive Engineers, 1984. (SAE paper, 840410).

OGATA, K. System dynamics. 3 ed. New Jersey: Prentice Hall, 1998. 758p.

PAULSTRA. Modeling of automotive anti- vibration rubber parts. s.L., 1998. Disponível em:<http://www.mscsoftware.com/support/library/conf/adams/euro/1998/euc98_05.pdf>.

RIVIN, E. I. Passive engine mounts: some directions for further development. In: INTERNATIONAL CONGRESS AND EXPOSITION, Detroit, Michigan, 1985. Papers. Warrendale: Society of Automotive Engineers, 1985. (SAE paper, 850481). 
SCHMITT R.V.; LEIGANG C. J. Design of elastomeric vibration isolation mounting system for internal combustion engines. In: ANNUAL EARTHMOVING INDUSTRY CONFERENCE, 27., Peoria, Illinois, 1976. Papers. Warrendale: Society of Automotive Engineers, 1976. (SAE paper, 760431).

SHANGGUAN W. B.; LU Z. H. Modeling of a hydraulic engine mount with fluidstructure interaction finite element analysis. Journal of Sound and Vibration. v.. 275, n.1-2, p. 193-221, ago. 2003. Disponivel em: <http://www.sciencedirect.com.>.

STRAW, R. L. The development of isolation mounts. In ANNUAL EARTHMOVING INDUSTRY CONFERENCE, 35., Peoria, Illinois, 1984. Papers. Warrendale: Society of Automotive Engineers, 1984. (SAE paper, 840781).

SWANSON, D. A. Active engine mounts for vehicles. In: INTERNATIONAL OFFHIGHWAY \& POWERPLANT \& EXPOSITION, Milwaukee, Wisconsin, 1993. Papers. Warrendale: Society of Automotive Engineers, 1993. (SAE paper, 932432).

TAYLOR, H. J, Jr. The new generation of engine mounts. 1986. In: INTERNATIONAL CONGRESS AND EXPOSITION, Detroit, Michigan, 1986. Papers. Warrendale: Society of Automotive Engineers, 1986. (SAE Paper, 862052).

TSUJIUCHI, N.; KOIZUMI T.; YAMAZAKI K.; SHIBAYAMA T. Vibration analysis of engine supported by hydraulic mounts. In: NOISE VIBRATION CONFERENCE AND EXPOSITION, Michigan, 2003. Papers. Warrendale: Society of Automotive Engineers, 2003. (SAE paper, 2003-01-1465).

YU Y.; NAGANATHAN N. G.; DUKKIPATI R. V. A literature review of automotive vehicle engine mounting systems. Mechanism and Machine Theory, v.36, n.1, p. 123-142, jan. 2001. 